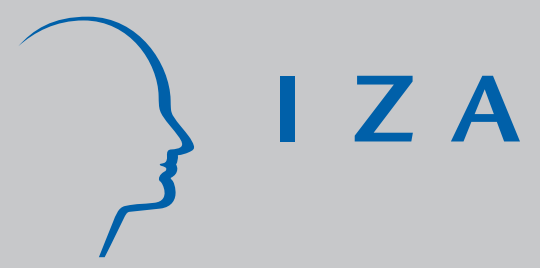

IZA DP No. 731

Educational Attainment: Analysis by Immigrant Generation

Barry R. Chiswick

Noyna DebBurman

February 2003 


\title{
Educational Attainment: Analysis by Immigrant Generation
}

\author{
Barry R. Chiswick \\ University of Illinois at Chicago and IZA Bonn \\ Noyna DebBurman \\ University of Illinois at Chicago \\ and W.E. Upjohn Institute for Employment Research
}

Discussion Paper No. 731

February 2003

\author{
IZA \\ P.O. Box 7240 \\ D-53072 Bonn \\ Germany \\ Tel.: +49-228-3894-0 \\ Fax: +49-228-3894-210 \\ Email: iza@iza.org
}

This Discussion Paper is issued within the framework of IZA's research area Mobility and Flexibility of Labor. Any opinions expressed here are those of the author(s) and not those of the institute. Research disseminated by IZA may include views on policy, but the institute itself takes no institutional policy positions.

The Institute for the Study of Labor (IZA) in Bonn is a local and virtual international research center and a place of communication between science, politics and business. IZA is an independent, nonprofit limited liability company (Gesellschaft mit beschränkter Haftung) supported by the Deutsche Post AG. The center is associated with the University of Bonn and offers a stimulating research environment through its research networks, research support, and visitors and doctoral programs. IZA engages in (i) original and internationally competitive research in all fields of labor economics, (ii) development of policy concepts, and (iii) dissemination of research results and concepts to the interested public. The current research program deals with (1) mobility and flexibility of labor, (2) internationalization of labor markets, (3) welfare state and labor market, (4) labor markets in transition countries, (5) the future of labor, (6) evaluation of labor market policies and projects and (7) general labor economics.

IZA Discussion Papers often represent preliminary work and are circulated to encourage discussion. Citation of such a paper should account for its provisional character. A revised version may be available on the IZA website (www.iza.org) or directly from the author. 
IZA Discussion Paper No. 731

February 2003

\section{ABSTRACT}

\section{Educational Attainment: Analysis by Immigrant Generation}

This paper presents a theoretical and empirical analysis of the largely ignored issue of the determinants of the educational attainment of adults by immigrant generation. Using Current Population Survey (CPS) data, differences in educational attainment are analyzed by immigrant generation (first, second, and higher order generations), and among the foreign born by country of birth and age at immigration. Second-generation American adults have the highest level of schooling, exceeding that of the foreign born and of the native born with native-born parents. Teenage immigration is associated with fewer years of schooling compared to those who immigrated at pre-teen or post-teen ages. The gender difference in educational attainment is greatest among the foreign born. Hispanics and Blacks lag behind the non-Hispanic whites in their educational attainment, with the gap narrowing for higher order immigrant generations among Hispanics, but rising among blacks.

JEL Classification: $\quad$ I21, J24, J61

Keywords: demand for schooling, human capital, immigrants, second generation

Corresponding author:

Barry R. Chiswick

Department of Economics (M/C 144)

University of Illinois at Chicago

601 South Morgan Street

Chicago, IL 60607-7121

USA

Tel.: +1 3129962683

Fax: +1312 9963344

Email: brchis@uic.edu 


\section{INTRODUCTION}

Immigration is a controversial labor and social issue in the United States, with significant impacts on present and future U.S. education. The pattern of immigration in the last few decades coupled with the tendency for ethnic differences in education attainment to persist over subsequent immigrant generations has led to an increasing gap in educational attainment between some of the fastest growing immigrant communities in the United States, and with the native-born population. At the same time, long-term structural changes in the U.S. economy have markedly increased the importance of education, making high-school completion a minimum requirement for any individual to compete successfully in the labor market. Thus, educational institutions in the U.S. today are faced with a twofold issue: one, to educate a larger and more diverse population and, two, to bridge the gap in educational attainment among the various ethnic groups. Immigration is also poised to strongly impact the future of U.S. education, as immigrants and children of immigrants increasingly account for a larger proportion of school age children, highlighting the need to better understand the educational attainment of immigrants.

This study makes a significant contribution to the immigration literature by conducting a systematic analysis of schooling acquisition by immigrant generation. In addition, this research also examines the effects of country of origin and age at immigration on immigrant education. A growing body of literature on the economic assimilation of immigrants has focused on human capital transfer, human capital investment, and the labor market adjustment of immigrants. Research on immigrant educational attainment is a fairly recent phenomenon. A persistent limitation is that most studies fail to distinguish between the different generations of U.S. residence. Secondgeneration immigrants (i.e. those born in the U.S. of one or two immigrant parents) are

typically grouped together either with first-generation immigrants (i.e. those who are immigrants themselves) or with native-parentage adults and children (i.e. those who are U.S. born with U.S. born parents).

Several reasons exist why an analysis by immigrant generation is crucial in understanding immigrant educational attainment. First, a continuous influx of immigrants 
into the U.S. in the past three decades has resulted in a significant proportion of the U.S. population today being comprised of second-generation Americans (i.e. children of immigrants), and this proportion will continue to grow in the foreseeable future. Second, while first-generation immigrants receive little or none of their education in the United States, second-generation immigrants, and native-parentage adults receive all their education in the United States. Third, the second-generation immigrants are a distinct group: they are born in the United States, but unlike native-parentage adults, immigrant influences through their parents play a crucial role in the formation of their human capital. An examination of educational attainment by immigrant generation will enable us to understand if educational differentials decrease with each successive generation, and will help recognize the intergenerational impact of ethnic background on educational outcomes.

For adult immigrants, education typically has two components - schooling completed in the home country prior to immigration, and schooling acquired in the destination country after immigration. Three studies on post-immigration schooling investment of immigrants stand out. Borjas (1982) and Hashmi (1987) have examined the determinants of post-immigration investment in education in the United States, and Chiswick and Miller (1994) have conducted a similar study for Australia. ${ }^{1}$ Both of the U.S. based studies have focused on men alone. But while Hashmi examined foreign-born men between 18 and 64 years, who migrated at age 15 and above, Borjas limited his analysis to Hispanic male immigrants between 18 and 64 years. Moreover, a limitation of both of these studies is that the datasets used necessitated that years of schooling in the United States be measured as a residual. ${ }^{2}$ Chiswick and Miller's (1994) analysis is more

1 A condensed version of Hashmi's 1987 analysis is reported in her later paper, Khan (1997).

2 The Survey of Income and Education used by both Borjas (1982) and Hashmi (1987), provided information on total years of schooling and pre-immigration schooling, with post-migration schooling estimated as total minus pre-immigration schooling. Hashmi (1987) also used the 1980 Census data and based on the assumption of continuous school attendance from age six, post-migration schooling was calculated as total years of schooling minus age at migration (which is current age minus years since migration). 
comprehensive since they analyzed the determinants of post-migration investment for all adult (age 25 to 64) immigrants in Australia and used data that provided explicit information on pre- and post- migration schooling.

The goal of this study is to focus on total schooling acquired (a stock concept) by adult immigrants rather than on post-migration investment in schooling (a flow concept). Unlike the earlier U.S. related studies, the research presented here includes both men and women, revealing any existing pattern in gender differences, if they exist. This study also expands on the existing literature specifically through its analysis by immigrant generation, and by age at immigration.

This paper proceeds as follows. Section II reviews the literature on immigrant education. Section III discusses the theory of human capital investment and the theory of demand for schooling, and uses them as a basis to formulate a theoretical model for studying immigrant schooling attainment. Section IV describes the October 1995 Current Population Survey, the dataset used for this study, as well as the estimating equations. The estimation results are described in Section V. Finally, conclusions and policy implications are summarized in the last section.

\section{REVIEW OF LITERATURE}

It is easiest to classify the existing literature on immigrant educational attainment into two broad group based on the research methodology and/or discipline. Anthropologists and sociologists have led the major work in this field and form the first group, while, in more recent years, economists have also become engaged to form the second group.

Among sociologists and anthropologists, two theories have dominated their research on educational attainment of U.S. immigrants: the cultural discontinuity theory and the cultural ecology theory. Proponents of the cultural discontinuity theory believe that immigrant youth are disadvantaged due to language, cultural, and social interactional conflicts between home and school (Carter and Segura, 1979; Trueba, 1987; Perlmann

Such procedures are likely to impart a negative correlation between measured postmigration years of schooling and measured pre-migration schooling. 
1988). In their studies, they find that immigrant attainment increases with increased duration of stay in the U.S. and more acculturation to American society. On the other hand, cultural-ecological theorists believe that immigrant attainment is affected by a complex interaction of multiple factors, that include motivation to immigrate, perceptions of opportunity, and labor market payoff for attainment (Ogbu, 1978; 1987; Ogbu and Matute-Bianchi, 1986). These latter theorists propose that ethnicity and generation together determine educational attainment. However, more recently, some studies have produced findings that do not always fully agree with one or the other of these two theories, nevertheless they represent important advances and are described below.

Several key studies specify that immigrant generation plays an important role in educational attainment and school performance (Portes and Rumbaut, 1990; Rong and Grant, 1992; Kao and Tienda, 1995). Usually, second-generation youth perform better academically (academic achievement was measured by middle school grades and standardized math and reading test scores) than first-generation youth or native born youth. But, first-generation youth who immigrate at very young ages often exhibit educational attainment similar to those attained by the second-generation youth. Most such studies also point out substantial effects of ethnicity on educational attainment (Rong and Grant, 1992; Kao, Tienda, and Schneider, 1996). Asians outperform other groups in attainment (Hirschman and Wong, 1986; Lee and Rong, 1988). Hispanic students, in particular, have lower achievement levels and higher dropout rates, compared to Asians and non-Hispanic whites (Arias, 1986; Velez, 1989). Furthermore, Rong and Grant (1992) examined the combined effects of immigrant generation and ethnicity on educational attainment. Their study found that immigrant generation affects youth educational attainment, but this influence is not consistent across generations and ethnicity.

Although, their foray into immigration research has been more recent, economists have made significant contributions focusing on two aspects of educational attainment: one, post-migration schooling of immigrants (Schultz, 1984; Hashmi, 1987; Khan, 1997; Chiswick and Miller, 1994; Chiswick and Sullivan, 1995); and two, patterns of the education attained by immigrants in their country of origin (Funkhouser and Trejo, 1995; Cohen, Zach and Chiswick, 1997). The key findings that have emerged from the post- 
migration schooling literature is that age at immigration coupled with duration of residence in the host country is a primary determinant of investment in schooling. Chiswick (1978) indicates that immigrants tend to make their largest human capital investments within the first few years of arriving in the host country. Moreover, as the duration of residence in the U.S. increases, the years of post-migration schooling increases, but at decreasing rate (Chiswick and Miller, 1994; Khan, 1997). Most studies of post-migration investment agree that in English-speaking destinations, foreign-born people from non-English speaking countries invest more in post-migration schooling than the foreign-born from English-speaking countries (Chiswick and Miller, 1994; Khan, 1997; Duleep and Regets, 1999; Cobb-Clark, et al., 2000). Furthermore, human capital investments in the destination tend to be lower when the cost of to-and-from migration to the home country is low (Borjas, 1982; Chiswick and Miller, 1994; Duleep and Regets, 1999).

Recently, several new studies have had considerable impact on our understanding of post-migration schooling. Schaafsma and Sweetman (1999) investigated the impact of age at immigration on educational attainment in Canada. They found that educational attainment varies systematically by age at immigration: immigrants arriving when they are between ages 15-18 acquire less total education than those who immigrate at a younger or older age. According to the authors, "adjusting to a new environment near the transition out of high school may have a permanent effect". Furthermore, Gang and Zimmerman (1999) indicated that the gap in educational attainment between immigrants in Germany and their comparable German-born cohort is much smaller in the secondgeneration compared to the gap in the first-generation, implying that assimilation exists in the acquisition of education. This finding is in line with Schultz (1984) and Betts and Lofstrom (2000), who found that the schooling level of children of immigrants in the U.S. converges toward that of the children of natives.

The studies on patterns of educational attainment indicate that the schooling level of immigrants to the U.S. exceeds the national average (Portes and Rumbaut, 1990). In studying immigrant cohorts, Borjas (1987) described a decline in the schooling level of immigrants in the 1970s, but Cohen, Zach, and Chiswick (1997) found that during the 1980s, this trend had stopped and had been reversed. 
Despite a growing body of literature on educational attainment, limitations persist. This paper is one of the few attempts in the literature that provides testable hypotheses which relate exclusively to the total schooling acquisition of immigrants at a national level. Moreover, it will extend previous studies by analyzing educational attainment by country of origin, by age at immigration and by immigrant generation.

\section{THEORY AND HYPOTHESES}

This study draws on the theory of investment in human capital developed by Schultz (1961) and Becker (1964). Human capital theory assumes that individuals invest in human capital in order to maximize their net wealth. Becker employed the investment framework primarily to analyze educational attainment and the rate of return to education for individuals. Chiswick $(1978,1979)$ extended Becker's human capital framework substantially through its application to studying labor market aspects of immigration. This modified human capital model has since been instrumental in analyzing the process of immigrant adjustment in the host-country labor market.

Chiswick (1978) was the first to argue that, for the same number of years of schooling, the ability to convert schooling into earnings might differ between the foreignborn and the native-born. This argument implied that immigrants would be unable to transfer completely the human capital accumulated in their home country to the labor market of the destination country. To analyze this aspect of immigration, Chiswick developed the phrase 'international transferability of skills'. International transferability of skills can be viewed as a function of similarities in the labor markets of the home country and the host country, schooling and language being two important indicators. Schooling has two components - an origin-specific component and an internationally transferable component. The importance of these two components differs by the level and the type of education attained by immigrants. The more general the skills acquired through schooling in the origin, the greater the transferability to the destination and hence the smaller the decline in value of skills upon migration.

The human capital investment framework discussed above is appropriate for testing hypothesis related to different types of human capital investments, such as, migration, schooling and on-the-job training. Therefore, this study uses the human 
capital framework for analyzing educational attainment and school enrollment. Within this framework, attention is focused on factors that affect the demand for schooling, particularly in the context of immigrants.

Becker (1967) developed a model of optimal schooling. The model's underlying assumption is that individuals face a demand schedule, which reflects the marginal rate of return on investments in schooling, and a supply schedule, which reflects the marginal interest cost of obtaining funds to finance the investment in schooling. Optimal investment occurs when the marginal rate of return on investment equals the marginal interest cost of funds. Chiswick (1988) reinterpreted Becker's model in the broader context of racial and ethnic groups. Chiswick argued that group differences in investment in schooling might arise from either differences in demand conditions, or differences in supply conditions, or from their combination. He further maintained that group differences in demand conditions vary more than group differences in the supply conditions, which in turn implies a positive relationship between levels of schooling and rates of return from schooling.

The main hypothesis that emerges from the preceding discussion is that the demand for schooling is determined by economic incentives. An increase in the costs associated with schooling will cause individuals to substitute away from education while an increase in the benefits from schooling will increase its demand. Based on the above discussion, the theoretical demand for schooling equation for immigrants can be expressed as a function of both pre-immigration conditions and the post-migration experience of immigrants.

Pre-immigration conditions and post-migration experience play vital roles in immigrant schooling investment decisions because they affect the level, and the transferability of skills that immigrants bring with them. While pre-immigration conditions include age at immigration, country of origin, and pre-immigration educational attainment, post-migration experience is associated with immigrant duration in the destination country.

For the foreign-born, total schooling has two components - schooling acquired before, and schooling acquired after migration. Hashmi (1987) and Borjas (1982) have examined post-migration investment in schooling by immigrants in the United States. 
While their studies represented important advances on the subject, a serious limitation of both the studies was the need to estimate years of schooling in the United States as a residual since such a procedure is likely to impart a negative correlation between measured post-migration years of schooling and measured pre-migration schooling. The datasets used for this study do not provide direct information on the division between preimmigration schooling and post-migration schooling either. Therefore, based on the assumption of continuous school attendance from age six, post-migration schooling would have to be calculated as total years of schooling minus age at migration (which is current age minus years since migration). Using this procedure to study post-migration schooling would not resolve any of the bias inherent in the existing studies of Hashmi and Borjas. Hence, this study focuses on total schooling, a relatively unexplored area rather than on post-migration investment in schooling. Moreover, often people first decide on the total level of schooling they will attain, and then decide on the location of their schooling. Consequently, the decision between pre- versus post- migration schooling becomes an endogenous one, which further justifies our study of total schooling.

For adult immigrants, age at arrival affects the costs of and returns from human capital investment. First, the older the age at immigration, the higher the opportunity costs associated with schooling (due to investment in the origin country). ${ }^{3}$ Second, the older the age at immigration, the shorter the duration in the host country to receive benefits from investment in destination specific skills. These factors make migration as well as investment in post-migration schooling more profitable for younger immigrants compared to older immigrants. This profitability in turn, implies that the enrollment in schooling in the destination will fall with age at migration, and holding age constant, with duration in the destination. Consequently, total schooling increases with age at a decreasing rate. While immigration at an early age is considered beneficial, recent evidence also points to a lower return to schooling for those immigrating in late teens

3 There are two costs associated with post-migration investment in schooling - the direct cost of schooling in the United States, and the indirect foregone earnings in the country of origin. Testing the effect of age on post-migration education provides an indirect index of the opportunity cost of foregone earnings, and this approach is used in this study. 
compared to those immigrating at a slightly younger or older age. Country of origin differences among immigrants arise from differences in the propensity for return migration. The higher the propensity for return migration, the lower is the incentive for immigrants to invest in education for themselves or their children that are destination specific. Moreover, the relation (substitute or complement) between pre-immigration and post-immigration schooling influences the total level of schooling attained in the destination country. ${ }^{4}$

Post-migration experience measured by duration in the destination is a particularly important index of the economic adjustment of immigrants. Whether or not an immigrant invests in destination specific schooling depends on some of the factors discussed earlier. However, if post-migration investments are made, they occur in the first few years after immigration and diminish thereafter (Hasmi 1987). This arises because of three reasons. One, investments that are profitable tend to yield greater returns the earlier they are made. Two, the sooner such investments are made, the lower is the opportunity cost of time since earnings rise with length of stay. Lastly, a delay in investment results in a shorter remaining working life in which to receive benefits from the investment. This investment pattern implies that the total level of schooling attained increases at a decreasing rate with an increased duration in the destination, and that current enrollment rates decrease with duration.

Based on the theoretical model discussed above, the following hypotheses have been developed:

4 Total schooling acquired may be affected by pre-immigration schooling in two ways. One is the quantity measure of pre-immigration schooling, which is years of schooling completed in the origin. Two, holding quantity constant, the quality of pre-immigration schooling may differ by country of origin. For example, the knowledge acquired through ten years of schooling in Mexico could be quite different from the same number of years of schooling in Sweden. In general, education systems in some countries are known to be more rigorous than others. While the importance of quality of pre-immigration schooling cannot be denied, it is difficult to obtain data measures of schooling by country-of-origin that would account for such differences, therefore, it $\dot{\mathrm{s}}$ beyond the scope of this work to investigate the qualitative effects of pre-immigration schooling on total schooling, other than through dichotomous country of origin (fixed effects) variables. 
The model of immigrant adjustment based on human capital theory suggests that the economic status of immigrants improves with their duration of stay, i.e., immigrant assimilation in the host country is positively related to length of stay. The assimilation literature focuses on the effect of duration of residence in the destination country on immigrant assimilation in the host country. Implicit in the concept of 'assimilation' is the impact of immigrant generation, if we further distinguish between the native-born who have at least one foreign-born parent (second-generation immigrants) and the native-born who have two native-born parents (native-parentage). Second-generation immigrants will likely out-achieve first-generation immigrants because the former possess more destination specific skills. Second-generation immigrants may out-achieve nativeparentage immigrants due to the positive influence of foreign-born parents arising from the selectivity bias in migration, which implies that immigrants tend to be disproportionately high ability or highly motivated people (Chiswick, 1977; 1999).

Hypothesis 1: Among immigrants, educational attainment will differ by immigrant generation. The second-generation of immigrants (children of immigrants) will exhibit higher educational attainment than the first-generation and may receive more schooling than those with native born parents.

Language is an important component affecting transferability of skills since the lower the immigrant's fluency in the destination language, the lower the transferability of the origin country skills. Furthermore, the lower an immigrant's transferability of skills, the greater the incentive to invest in destination specific human capital because of the positive effect that destination country education has on increasing the transferability of origin-country skills.

Hypothesis 2: Among immigrants, educational attainment will differ by country of origin. Immigrants to the U.S. from non-English speaking countries will exhibit a higher demand for investments specific to the U.S. but will be handicapped by their lesser proficiency in English. 
Age at immigration affects labor market outcomes both directly and indirectly. The direct impact of age at immigration on labor market outcomes is easily explained in terms of costs and benefits. A higher age at immigration is associated with a higher opportunity cost of schooling and job training (due to previous investment) coupled with a shorter remaining working life in the destination labor market to receive benefits. The direct impact of age at immigration is due to schooling and labor market experience in the source country not being recognized as equivalent to schooling and experience in the host country. The indirect impact of age at immigration stems from the fact that younger immigrants are more able to adjust to linguistic and cultural challenges associated with migrating to a new country. For example, children have a superior ability to acquire new language skills, and this diminishes with age. Moreover, the complementarity between destination language and other forms of human capital (schooling) also suggests that youth will accrue more benefits from undertaking any destination specific investment (Chiswick and Miller, forthcoming). In light of these effects, we can expect postmigration years of schooling (a component of total schooling) to fall with age at immigration 5 .

Hypothesis 3: Educational attainment will vary with age at immigration. Specifically, post-migration educational attainment will tend to fall with age at immigration, and fall at a decreasing rate.

\section{DATA AND ESTIMATING EQUATIONS}

The empirical analysis discussed in this paper is based on data from the October 1995 Current Population Survey. The Current Population Survey (CPS) is a monthly survey of about 57,000 households conducted by the Bureau of the Census for the Bureau of Labor Statistics (U.S. Bureau of the Census 1995). Respondents are interviewed to obtain information about the employment status of each member of the household 15 years of age and older. Each household is interviewed once a month for

5 Another variable that reflects post-migration investment in schooling is the current enrollment status of the immigrant. While the importance of analyzing current enrollment status in a study of educational attainment is recognized, it is beyond the scope of this work. 
four consecutive months one year, and again for the corresponding time period a year later. Each month new households are added and old ones are dropped and thus part of the sample is changed. The CPS sample is scientifically selected on the basis of area of residence to represent the nation as a whole, individual states and other specified areas. The unit of observation in the CPS is the household, but the data are collected on each household member.

The basic CPS provides information on employment, unemployment, earnings, hours of work, and other labor force indicators on all household members above 16 years old. Such data are available by a variety of demographic characteristics including age, sex, race, marital status, and educational attainment. In addition to the basic demographic and labor force questions, questions on selected topics (school enrollment, income, employee benefits, and work schedules) are included as supplements to the regular CPS questionnaire in various monthly surveys. These supplemental topics are usually repeated in the same month each year. Information on immigrant year of entry to United States and information on a respondent's parental place of birth is vital to this study. Only the post-1994 CPS surveys provide this information, and the October 1995 CPS was used for this study. The question used for defining the dependent variable, educational attainment was as follows: What is the highest level of school completed or the highest degree received by the person? Sixteen response categories exist: less than $1^{\text {st }}$ grade, grades 1 to 4, two categories for middle school, five categories for high school, four categories for college, and, three categories for graduate school. The remaining variable definitions are provided in Table A-1 in the Appendix.

\section{The Sample}

The total sample size of the 1995 CPS was 148,392 individuals. For this study, the non-interviewed records from the sample were excluded, reducing the sample size to 134,946 individuals. The study of educational attainment was conducted for all adults between 25 and 64 years. The relevant sample size was 69,746. The population studied was first-generation immigrant adults, second-generation immigrant adults, and nativeparentage adults. 'First-generation immigrant adults' were defined as those adults born outside the United States, who immigrated either as children or as adults. 'Second- 
generation immigrants adults' were defined as those adults born in the U.S., but having one or both foreign-born parents. 'Native-parentage adults' were defined as those adults born in the U.S. of U.S.-born parents. Adults born in outlying areas of the United States, such as Puerto Rico, as well as adults born of American parents living abroad were excluded from this analysis. Also excluded were adults who have both parents born in Puerto Rico and other U.S. outlying areas. The size of the first-generation adult sample was 7,496; that of the second-generation adult sample 4,506, and native-parentage adult sample 56,483. Therefore, the pooled sample size was 68,485. The data on period of immigration is for when the person first came to the United States to stay. The visa under which the respondent entered or the motive for migration are not known. It is therefore not possible to identify those first-generation immigrants who entered the United States on student visas.

\section{The Estimating Equation}

The explanatory variables in the educational attainment equation were of the following types: Human Capital Variables (age, years since immigration), Control Variables (marital status, south, MSA, black, hispanic, and male), and Country of Origin Variables.

The basic estimating equation for educational attainment was written as:

$$
\text { Educational attainment }=f(\mathrm{H}, \mathrm{D}, \mathrm{G}, \mathrm{C})
$$

$\mathbf{H}$ is a vector of human capital variables, including age and age at immigration. Age is expected to have a positive impact on educational attainment. To test the rate of increase of educational attainment with age, age squared was introduced into the estimating equation. $^{6}$ Years since migration (YSM) measures the number of years that an immigrant has resided in the host country. Age at immigration (AGEIMMIG) captures

\footnotetext{
6 The age variable captures two effects - one, the cohort effect (younger cohorts acquire more education) and two, the life cycle effect (education increases with age in the life cycle). Due to the secular increase in schooling, beyond a certain point the negative cohort effect of an older age dominates the positive life cycle effect.
} 
the impact of immigration at different ages. There are three concepts of age important in the context of the foreign-born: current age of an immigrant, age at the time of immigration, and years since migration. The three age variables are, however, collinear therefore, given any two of them in the regression, the effect of the third can be calculated.

For ease of interpretation, this study used the variables, $\mathrm{AGE}, \mathrm{AGE}^{2}$, and AGEIMIG, AGEIMIG ${ }^{2}$. As an immigrant's length of stay in the U.S (YSM) increases, his stock of investment in U.S. schooling increases but at a decreasing rate. Therefore, holding age constant, as age at immigration increases, post-migration educational attainment is expected to fall but at a decreasing rate. Furthermore, following Schaafsma and Sweetman's (1999) decomposition of age at immigration into several age at immigration classes, in an immigrant earnings analysis for Canada, this study incorporates eight age at immigration dummy variables (e.g., age at immigration $=0$ to 4 , 5 to 12 , and so on) to capture the differing effects of immigrating over particular ageranges.

D is a vector of demographic control variables for gender, marital status, and race/ethnicity. Dichotomous variables for being black and hispanic were used to measure the impact of racial disadvantage on educational attainment, male was used to control for

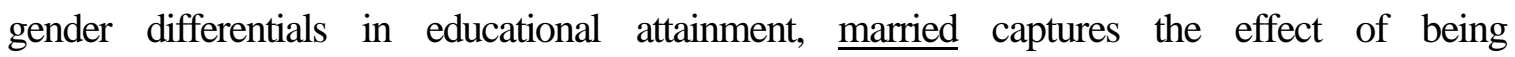
married as distinct from other marital statuses. G is a vector of geographic variables. Dichotomous variables, south, representing south/non-south residence, and MSA, representing metropolitan/non-metropolitan residence, controls for the effect of region of residence and urbanization on educational attainment, respectively.

C is a vector of country of origin dummy variables to capture country fixed effects, including the impact of the transferability of skills and motive for migration. Based on the assumption that economic migrants from English speaking developed countries possess highly transferable skills, the benchmark group created for the country of origin analysis was English-speaking developed countries. Other countries were clustered into broad groups to represent economic migrants from certain major nonEnglish speaking countries and also refugee migrants from other countries. When applying the estimating equation to the pooled sample of native-born and foreign-born, 
native-born were the benchmark in the $\mathrm{C}$ vector, so a dichotomous variable for the English-speaking countries was added to the equation.

\section{EMPIRICAL ANALYSIS}

\section{Summary Statistics}

Comparative statistics for all adult (25-64 year old) natives, and first- and secondgeneration immigrants are summarized in Table 1. An average first-generation immigrant is 41 years of age, has 11.8 years of schooling, and has been in the United States for about 16 years. The average second-generation immigrant is 45 years of age, and has an education level of 13.7 years, in contrast to the native parentage age of 42 years and 13.5 years of schooling. Furthermore, the natives are more southern (38 percent) than either the first-generation or second-generation ( 24 percent each). Compared to 22 percent of native-parentage living in non-metropolitan areas, only 11 percent of second generation immigrants and even fewer (5 percent) first-generation immigrants live in nonmetropolitan areas. The first-generation has a large percentage of Hispanics (47 percent) compared to the second-generation (20 percent) and native-parentage ( 3 percent) adults.

\section{Regression Analysis}

This section first discusses the pooled sample of first-generation, second generation, and native-parentage adults. Separate regressions by immigrant generation in the next three sub-sections allow a comparative study of the determinants of educational attainment between the three groups. The first-generation sample also allows us to study educational attainment by different countries of origin, and different ages at immigration.

\section{Pooled Sample}

Ordinary Least Square regressions were run using the 1995 CPS data. The dependent variable for the regression equation was years of schooling, referred to as 'educational attainment'. Three different specifications of the equation were considered. The primary explanatory variables used in all three specifications were male, age, age squared, black, Hispanic, married, South, non-MSA, age at immigration and age at immigration squared. The basic specification (column 1 in table 2) was a simple model, which used the above-mentioned set of demographic and geographic variables as the explanatory variables along with the two immigrant generation variables. The second 
specification (column 2 in table 2) added birthplace dummy variables to the set of explanatory variables. The last specification (column 3 in table 2) deleted the quadratic age at immigration variables but added age at immigration dummy variables as regressors.

We first discuss the analysis of the pooled sample of native-born and foreign-born population. Focusing on model (1) of the regression for the total pooled population, the positive sign of age coupled with the negative sign of age squared shows an increase in education with age but at a decreasing rate. The peak occurs at 32.5 years, after which the effect of age on education becomes negative. The age variable captures two effects - one, the cohort effect, which implies that younger cohorts acquire more education, and two, the life cycle effect, which implies that education increases with age in the life cycle within a cohort. Apparently, beyond age 32.5 years, the negative cohort effect dominates the positive life cycle effect.

The effect of foreign birth on educational attainment (irrespective of the country of origin) is given jointly by the coefficients of variable 'first- generation' and the variables on 'age at immigration' ${ }^{7}$. The negative and positive coefficients of age at immigration and age at immigration squared, respectively, indicate that educational attainment decreases with age at immigration, and it decreases at a decreasing rate. Evaluated for different values of age at immigration, the partial effect of being a firstgeneration immigrant on educational attainment is: 0.52 years for age at immigration $=1$, 0.23 years for age at immigration $=5,-0.01$ years for age at immigration $=10,-0.47$ years for age at immigration $=20$, and -0.86 years for age at immigration=30. Clearly, the effect of foreign-birth (being a first-generation immigrant) on educational attainment depends on age at immigration. Only those immigrating at a very early age will have attainment levels similar to their native counterparts. However, the positive coefficient of secondgeneration clearly indicates that second-generation immigrants acquire 0.47 years more of total schooling than native-parentage adults.

7 If Education $=\ldots \ldots \ldots .+b_{1}$ (First-generation $)+b_{2}$ (Ageimmig)*(First-generation $)+b_{3}$ (Ageimmig) $^{2} *($ First-generation) $+\ldots$, then taking derivatives, $\delta$ (Education) $/ \delta$ (Firstgeneration $)=b_{1}+b_{2}($ Ageimmig $)+b_{3}(\text { Ageimmig })^{2}$. 
The remaining coefficients in the estimating equation are all highly significant. Men attain 0.14 years more of education than women. Being black reduces educational attainment by 0.69 years, and being Hispanic decreases educational attainment by a very large 2.59 years. Residence in the southern states or in a non-metropolitan area is associated with a negative impact on educational attainment. Being married is associated with 0.31 more years of education.

The second specification (Table 2, column 2) included the usual explanatory variables plus the country variables representing all countries of origin. The benchmark was native-parentage adults, hence holding all other coefficients constant, the coefficients represent the difference in education between first-generation immigrants from a particular country and native-parentage adults. The coefficients indicate that Africans, South Asians, and North and West Europeans acquire 3 years more of education, and Philippines, East Asians, East and Central Europeans and Middle-Easterners about 2 more years compared to all native-parentage adults. Cubans, Chinese and immigrants from English-speaking countries acquire between 1.0 and 1.5 years more of education compared to native-parentage adults. The positive differential is negligible for immigrants from South and Central America.

Immigrants from Mexico and Southern Europe have lower levels of educational attainment compared to all native parentage adults. The differential is 2.5 years for Mexicans and 1.4 years for Southern Europeans ${ }^{8}$. The inclusion of the country of origin variables is associated with a change in the estimated impact of the variable Hispanic. For Hispanic, the partial effect changes from -2.59 to -1.32 . This change in the magnitude of the Hispanic variable can be attributed to the large negative coefficient of Mexico. Thus a Hispanic from Mexico (as are nearly all Mexican immigrants) would have 3.8 fewer years of schooling, other variables the same, than native parentage non-Hispanic adults.

Specification 3 (column 3 in table 2) included the usual explanatory variables (without the age at immigration quadratic variables) plus the age at immigration dummy variables. The benchmark was all native-parentage adults, hence the age at immigration

8 This finding for Southern Europe is consistent with the Miller and Volker (1989) finding for Australia that immigrants from these countries were more focused on their children's education than on their own educational attainment. 
coefficients give the difference in education between foreign-born people from a particular age at immigration group and native-parentage adults. Our analysis indicates that adults immigrating in the 0 to 4 age-group acquire 0.8 years more of education, and those immigrating in the 5 to 12 age-group acquire 0.4 year more years of education compared to the benchmark group. Also relative to all native-parentage adults, firstgeneration immigrants migrating between ages 13 and 19 acquire 1.03 fewer years of education, those between ages 20 and 24 acquire about 0.8 years less of education, and between ages 25 and 29 acquire 0.41 fewer years of education. For foreign-born adults immigrating after age 30, the differential with their native parentage counterparts gets progressively larger with age.

The quadratic specification on age at immigration using the CPS data simply depicted a negative relation between age at immigration and educational attainment. When plotted graphically, this relationship appears as a smooth downward slope curve (Figure 1A). The specification with the age at immigration dummies portrays a more detailed picture. When educational attainment is plotted graphically (Figure 1B) against the age at immigration categories, we observe a dip at age at immigration 13-19 years and a local peak at 25-29 years. The age at immigration dichotomous variables indicate that educational attainment falls with an increase in age at immigration. However, it also captures an additional effect not obvious from the quadratic specification results, that is, immigrating in the years associated with secondary schooling conveys a greater disadvantage that does not arise if the immigration took place a few years earlier or later.

\section{First-Generation Sample}

This section discusses the results for the sample of 7,496 first-generation adults between 25 to 64 years old. Table 3 presents the means and standard deviations of educational attainment and age at immigration by country of origin. As column 1 indicates, approximately 9 percent of immigrants are from English-speaking countries (United Kingdom, England, Australia, New Zealand, British West Indies). The dominant immigrant source country is Mexico (22 percent), followed by South and Central America (12 percent), East and Central Europe (9 percent), Philippines (6 percent), and Southern Europe and East Asia (5 percent). The remaining country-groups constitute 1 to 4 percent each. 
Column 2 in Table 3 indicates that immigrants from South Asia, Africa, and North and West Europe have the highest level of schooling (15 years), followed by those from East Asia, Middle East, Philippines, China, and, East and Central Europe (14 years), North and West Europe, and English-speaking countries (13 years), followed by those from Cuba, Caribbean, Southern Europe, South and Central America and Other Asia (11 years). Immigrants from Mexico have the lowest level of education (9 years). The mean values of age at immigration (Table 3, column 3) by country of origin group reflects that immigrants from Southern Europe, and North and West Europe, Cuba and Mexico tend to migrate at a much younger age (20-24 years) compared to those from East Asia, Vietnam and China (28-31 years) who are disproportionately refugees. The other country groups lie in between the two extremes.

Table 4 presents the means and standard deviations of educational attainment by different age at immigration groups. Immigrants who migrate prior to their teenage years have schooling levels very close to the native-born. While the native-born have a mean schooling level of 13.5 years, those immigrating between 0 and 4 years acquire an average 13.7 years of schooling, with the 5 to 12 group following very closely at 13 years. The 13 to 19 age group attains an average of 11.2 years of schooling, which is lower than any group immigrating between 20 and 44. Moreover, those migrating between 25 and 29 have a slightly higher average (12.2 years) compared to the age-group prior to (11.6 years) or age-group after (11.9 years) them. Educational attainment is lowest for those immigrating after age 45, reflecting the world wide secular rise in schooling.

Ordinary Least Squares regression results for the first-generation immigrant sample are summarized in Table 5. Three different specifications corresponding to specification 1, 2, and 3 of the pooled sample are considered for the first-generation sample. The basic specification indicates that educational attainment increases with age until age 29, after which it starts declining due to younger cohorts receiving more schooling. The negative sign of age at immigration together with the positive sign of age at immigration squared implies that as age at immigration increases, educational attainment falls but at a decreasing rate. Evaluated for different values of age at immigration, the partial effect of age at immigration on educational attainment is: -0.05 
years for age at immigration=1, -0.05 years for age at immigration=10, -0.04 years for age at immigration $=20,-0.04$ years for age at immigration $=30$, and -0.03 years for age at immigration $=40$. Not all the remaining coefficients are significant.

Foreign-born men acquire about 0.46 years more schooling compared to foreignborn women. Residence in southern states increases educational attainment among the foreign-born by 0.31 years, while a non-metropolitan residence decreases educational attainment by 0.70 years. Being Hispanic has a highly significant negative effect on educational attainment (3.88 years).

The next specification (Table 5, column 2) introduced the country of origin regressors. In analyzing the first-generation sample, the benchmark group was the English-speaking foreign countries. Therefore, the coefficient of the country variables is interpreted as the difference in years of schooling between first-generation immigrants from a particular country group and first-generation immigrants from English-speaking countries. Immigrants from Africa, Philippines, East and South Asia, Middle East, and Europe (except southern) show higher levels of educational attainment than those from the English speaking countries. Immigrants from South and Central America, the Caribbean, Vietnam, Southern Europe and Mexico show lower levels of educational attainment than English speaking countries. Mexicans have the largest differential (4.2 years), followed by Southern Europe (3 years), and the remaining country-groups have less than one-year differential. The differential for Hispanics goes down from a highly significant -3.88 to a much less significant -1.09 , but the negative effect of Hispanic on educational attainment is clearly captured by the significant, large negative coefficient for Mexico. Hispanics born in Mexico have 5.3 years of schooling less than those from the English-speaking countries.

The last specification (Table 5, column 3) includes the usual explanatory variables plus the age at immigration dummy variables. In analyzing the first-generation sample, the benchmark age at immigration was the 25-29 age group. Our analysis indicates that adults who immigrated between the ages of 0 to 4 acquire 1.1 more years of schooling, and those who migrated between age 5 and 12 acquire 0.8 more years of schooling compared to the benchmark group, those who immigrated between ages 25 and 29 . Adults immigrating in the 13 to 19 and 20 to 24 age groups and those who immigrated at 
age 30 and older have less schooling than the ages 25 to 29 years group. The differential is less than one-half of a year, except for the oldest group (age 45 to 64 at immigration). In summary, the 13-19 group and 20-24 group acquire lower education compared to the 25-29 age-group, as do immigrants with older age at arrival. Moreover, the total years of schooling declines progressively in relation to the benchmark group for those immigrating after age 34 .

The summary statistics discussed in Table 1 indicated a large proportion of the first-generation sample to be Hispanic. To test if the Hispanic sample dominates the results derived from our analysis of the foreign-born sample, the basic specification (only demographic and geographic variables) and the specification with age at immigration dummies were run separately on the Hispanic sample and the non-Hispanic sample (see Table 6). The regression coefficients in the Hispanic sample differ from the coefficients in the non-Hispanic sample.

While being black increased educational attainment by 2.5 years among Hispanics, being black reduced educational attainment by 0.8 years among non-Hispanics (table 6). The black/non-black differential in schooling attainment between the Hispanic and non-Hispanic samples is perhaps explained by the fact that black Hispanics originate primarily from the Caribbean or Central America, and not from Mexico.

Being married does not have a significant effect in the Hispanic sample but has a positive effect on educational attainment for the non-Hispanic sample.

Another major difference noted between the Hispanic and non-Hispanic sample is the effect of age at immigration. The Hispanic sample clearly depicts that educational attainment decreases with age at immigration at an increasing rate but for the nonHispanic sample, the age at immigration variable is insignificant. What emerges from the age at immigration dummies is that among Hispanics, child immigrants (those immigrating prior to age 12) acquire $2 \frac{1}{2}$ to 3 years more education than adult immigrants. However, among non-Hispanics, those immigrating at 25-29 acquire more education than those immigrating at earlier years. Among non-Hispanics, but not among Hispanics, there is a very large negative effect of immigrating in the 13 to 19 age-group. 
Comparative Study of First-Generation, Second-Generation and Native-Parentage Adults

Regressions estimated separately for the first-generation immigrants, secondgeneration immigrants, and native-parentage adults are presented in Table 7. While educational attainment increases to age 37, and declines thereafter, for both secondgeneration immigrants and native-parentage; first-generation immigrants reach their peak much earlier at age 28. One noteworthy factor is the variation in the Hispanic/nonHispanic differential in educational attainment across the three groups of study. The Hispanic/non-Hispanic differential is most pronounced in the first-generation (3.9 years), followed by the second-generation (1.7 years), and the native-parentage group (1.3 years).

In order to study the effect of foreign-parentage on educational attainment, we consider the sample of all native-born adults (i.e., second-generation and nativeparentage adults). We introduced three variables (mother only foreign-born, father only foreign-born, and both parents foreign-born) into the basic regression specification. The benchmark is both parents being native-born.

Our results indicate that having either parent foreign-born or both parents foreignborn has a positive effect on educational attainment. Compared to the native parentage, a foreign-born mother is associated with 0.4 years more schooling, a foreign-born father with 0.34 more years, but if both are foreign-born only 0.21 more years. This result agrees with the Schultz (1984) finding that if both parents are foreign-born, duration of residence in the United States is associated with increased levels of schooling. Also if immigrants are favorably self-selected and more able (Chiswick, 1977, 1999), it suggests that they are more inclined to invest in their children's schooling than native-born parents. Therefore, it is not surprising that second-generation immigrants (who by definition have at least one foreign-born parent) acquire more schooling than their nativeborn counterparts.

\section{CONCLUSIONS}

Given the importance of immigrants in the U.S. workforce and increasing awareness of the critical role of education in labor market success, this study sought to investigate the determinants of the educational attainment of immigrants and the U.S.- 
born children of immigrants. This paper contributes to the existing literature on education by examining the educational aspect of the assimilation process of immigrants, through the separate investigation by first-generation and second-generation immigrants, and analyses among immigrants by age at immigration, and country of origin.

Based on the regression estimates, this paper's major finding is that educational attainment differs significantly among the three immigrant generations. Secondgeneration Americans acquire about half a year more schooling than their nativeparentage counterparts. Other explanatory variables (age, gender, marital status) held constant, those who immigrate at a very young age (up to age 4) acquire 0.35 years more schooling than second-generation, and 0.81 years more schooling than native-parentage adults. However, migration from age five up to age nineteen is associated with less schooling than second-generation immigrants, and immigration from age thirteen up to age nineteen is associated with fewer years of schooling even relative to native-parentage adults. Immigration in the teenage years (ages 13 to 19) appears to convey the greatest disadvantage. Those who migrate late in the twenties (age 25 to 29) complete more schooling (about half a year) than those migrating in their teen years. However, the attainment level drops significantly, and progressively with age at immigration beyond thirty. Thus the empirical analysis supports the hypothesis regarding the negative effect of age at immigration on post-migration investment in schooling, but the estimated relationship is complex, with a big dip among those who immigrate as teenagers.

Another major finding is the substantial heterogeneity that exists among immigrants depending on their country of origin. Immigrants from Africa, South and East Asia, Philippines, and North and Western Europe obtain 1.0 to 1.5 years more schooling in comparison to their counterparts born in the U.S. or immigrants from English-speaking countries. Mexicans and Southern Europeans, on the other hand, acquire less schooling relative to the native-born adults, as well as immigrants from English-speaking countries. Mexicans lag behind their U.S.-born, and their English-speaking birthplace immigrant counterparts by about 4 years. The lower education of Mexican immigrants can be attributed to the nature of migration from Mexico to the United States, a large percentage being illegal immigrants who have less economic incentive to invest in human capital. Additionally, given the close proximity of Mexico to the United States, costs of to- and- 
fro migration are very low, and this factor leads to a weaker incentive to invest in both origin-specific and destination-specific skills.

The analysis also indicates that being black, and more so being Hispanic, is associated with lower levels of education compared to non-Hispanic whites and Asians for immigrants, second-generation Americans and native-parentage adults. The black/non-black differential is less than a year (0.7 years) but the Hispanic/non-Hispanic differential is about 2.5 years. While the Hispanic/non-Hispanic differential is less pronounced with each subsequent generation, the black/non-black differential persists, and, in fact, is greatest in the native-parentage generation.

There are also gender differentials. Immigrant women acquire about half a year less schooling than immigrant men. This differential narrows with each successive generation.

The policy implications of our findings are significant, particularly for the minority groups studied. It would seem appropriate to enact appropriate immigration, assimilation and education policies not only to prevent the existing educational gap from widening any further, but also to narrow the existing gap.

Two kinds of policy can be used to influence the education levels of the immigrant population. First, immigration policy can be used to reduce the existing gap among various ethnic groups by restricting immigration among adults to those with some specified minimum level of schooling. Second, assimilation policy can be used to help immigrants, adults as well as children, assimilate into the host country, particularly in overcoming language and education barriers. The analysis indicates that racial/ethnic differences are most prominent in the first-generation among Hispanics. For example, assimilation policy involving increased commitment to the education of immigrants though emphasis on the acquisition of English language skills can play a major role in facilitating the adjustment and progress of Hispanic immigrant children whose parents typically have little education and/or do not speak English. 


\section{REFERENCES}

Arias, Beatriz M. (1986): "The Context of Education for Hispanic Students: An Overview." American Journal of Education. 95; 26-57.

Becker, Gary S. (1964): Human Capital: A Theoretical and Empirical Analysis, with Special Reference to Education 2nd edition, New York: National Bureau of Economic Research, Columbia University Press.

Becker, Gary S. (1967): Human Capital and the Personal Distribution of Income, Wyotinsky Lecture, No. 1, University of Michigan, Ann Arbor.

Betts, Julian R., and Magnus Lofstrom (2000): "The Educational Attainment of Immigrants: Trends and Implications." In: George J. Borjas, ed., Issues in the Economics of Immigration. University of Chicago Press: pp. 51-117.

Borjas, George J. (1982) "The Earnings of Male Hispanic Immigrants in the United States." Industrial and Labor Relations Review. 35(3); April: 343-353.

Borjas, George J. (1987): "Self-Selection and the Earnings of Immigrants." American Economic Review: 77 (4); 531-553.

Borjas, George J., (1995): School Enrollment Supplement: Technical Documentation, U.S. Bureau of the Census, Washington, D.C., October.

Carter, Thomas P. and Roberto D. Segura (1979): Mexican Americans in School: A Decade of Change. New York: College Entrance Examination Board.

Chiswick, Barry R. (1977): "Sons of Immigrants: Are They at an Earnings Disadvantage?" American Economic Association, Papers and Proceedings. 67(1), February, 376-380.

Chiswick, Barry R. (1978): "The Effect of Americanization on the Earnings of Foreignborn Men." Journal of Political Economy. 86 (5); October, 897-922.

Chiswick, Barry R. (1979): "The Economic Progress of Immigrants: Some Apparently Universal Patterns." In: Contemporary Economic Problems 1979, in William Fellner (ed.), Washington: American Enterprise Institute for Public Policy Research, pp. 359-399.

Chiswick, Barry R. (1988): "Differences in Education and Earnings across Racial and Ethnic Groups: Tastes, Discrimination, and Investments in Child Quality." Quarterly Journal of Economics. 103 (3); 571-97.

Chiswick, Barry R. (1999): “Are Immigrants Favorably Self-Selected?" American Economic Review. 89(2); 181-185. 
Chiswick, Barry R. and Paul W. Miller (1994): "The Determinants of Post-immigration Investments in Education." Economics of Education Review. 13 (2); 163-177.

Chiswick, Barry R. and Paul W. Miller (forthcoming): "The Complementarity Between Language and other Human Capital: Immigrant Earnings in Canada." Economics of Education Review.

Chiswick, Barry R. and Teresa A. Sullivan (1995): "The New Immigrants." In Reynolds Farley (ed.), State of the Union: America in the 1990's. New York: Russell Sage Foundation, pp. 211-270.

Cobb-Clark, Deborah, M.D. Connolly, and Chris Worswick (2000): "The Job Search and Education Investments of Immigrant Families." Research School of the Social Sciences, Australian University, Unpublished Paper

Cohen, Yinon, Tzippi Zach, and Barry R. Chiswick (1997): "The Educational Attainment of Immigrants: Changes over Time." Quarterly Review of Economics and Finance. 37 (Special Issue 1997); 229-243.

Duleep, Harriet, and Mark C. Regets (1999): "Immigrants and Human-capital Investment." American Economic Review. 89 (2); 186-191.

Funkhouser, Edward and Stephen J. Trejo (1995): "The Labor market Skills of Recent Immigrants: Evidence from the CPS." Industrial and Labor Relations Review. 48 (4); 792-811.

Gang, Ira N. and Klaus F. Zimmerman (1999): "Is Child Like Parent? Educational Attainment and Ethnic Origin." Center for Economic Policy Research, Discussion Paper. No. 57.

Hashmi, Aliya (1987): "Post-Migration Investment in Education by Immigrants in the United States." Ph.D. Dissertation. University of Illinois at Chicago.

Hirschman, Charles and Morrison G. Wong (1986): "The Extraordinary Educational Attainment of Asian Americans: A Search for Historical Evidence and Explanations." Social Forces. 65 (1); 1-27.

Kao, Grace and Marta Tienda (1995): "Optimism and Achievement: The Educational Performance of Immigrant Youth.” Social Science Quarterly. 76 (1); 1-19.

Kao, Grace, Marta Tienda and Barbara Schneider (1996): "Racial and Ethnic Variation in Academic Performance Research." Sociology of Education and Socialization 11; 263-97. 
Khan, Aliya Hashmi (1997): "Post-Migration Investment in Education by Immigrants in the United States." Quarterly Review of Economics and Finance. 37 (Special Issue 1997); 285-313.

Lee, Everett S., and Xue-Lan Rong (1988): "The Educational and Economic Achievement of Asian Americans." Elementary School Journal. 88 (5); 545-560.

Miller, Paul W. and Paul A. Volker (1989): "Socioeconomic Influences on Educational Attainment." Australian Journal of Statistics. Special Volume 31A, Youth Employment and Unemployment, August: 47-70.

Ogbu, John U. (1978): Minority Education and Caste: The American System in CrossCultural Perspective. New York: Academic Press.

Ogbu, John U. (1987): "Variability in Minority School performance: A Problem in Search of an Explanation." Anthropology and Education Quarterly. 18 (4); 313334.

Ogbu, John U. and Maria E. Matute-Bianchi (1986): "Understanding Sociocultural Factors: Knowledge, Identity, and School Adjustment." In Beyond Language: Social and Cultural Factors in Schooling Language Minority Students. Los Angeles: Office of Bilingual Bicultural Education, pp. 73-142.

Perlmann, Joel (1988): Ethnic Differences. Cambridge: Cambridge University Press.

Portes, Alejandro and Ruben G. Rumbaut (1990): Immigrant America. Berkely: University of California Press.

Rong, Xue-Lan and Linda Grant (1992): "Ethnicity, Generation, and School Attainment of Asians, Hispanics and Non-Hispanic Whites." The Sociological Quarterly. 33 (4); 625-636.

Schaafsma, Joseph and Arthur Sweetman (1999): "Immigrant Earnings: Age at Immigration Matters." Canadian Journal of Economics. 34(4); 1066-99.

Schultz, T. Paul (1984): "The Schooling and Health of Children of U.S Immigrants and Natives." Research in Population Economics. 5, 251-288.

Schultz, Theodore W. (1961): "Investment in Human Capital." American Economic Review. $51(1) ; 1-17$.

Trueba, Henry (1987): Success or Failure? Learning and the Language Minority Student. Cambridge, MA: Newbury House.

U.S. Bureau of the Census (1995). School Enrollment Supplement: Technical Documentation, Washington, D.C., October. 
Velez, William (1989): "High School Attrition among Hispanic and Non-Hispanic White Youths." Sociology of Education. 62 (2); 119-133. 
Figure 1: Effect of age at immigration on educational attainment

A. Quadratic Specification of Age-at-Immigration Variable

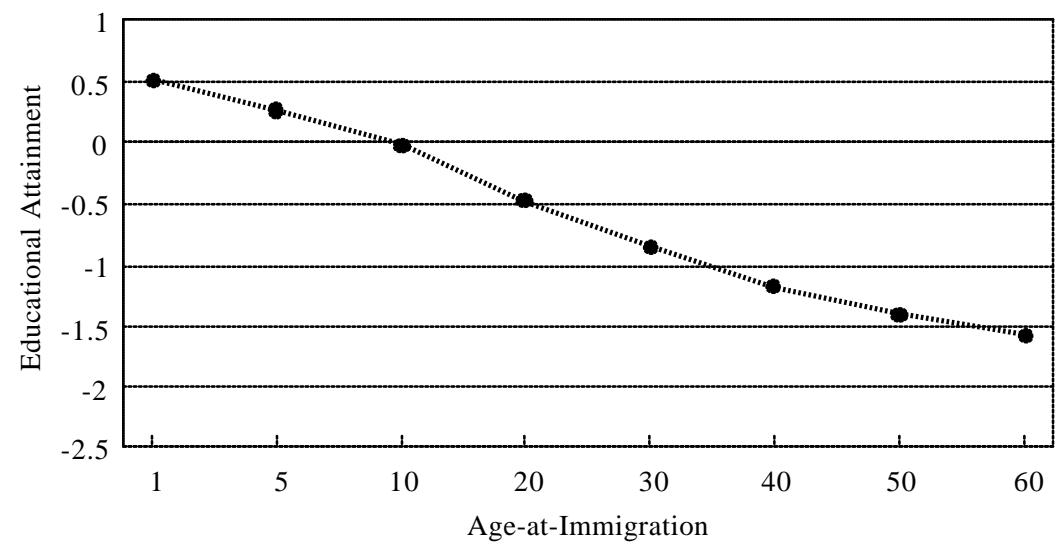

B. Categorical Specification of Age-at-Immigration Variable

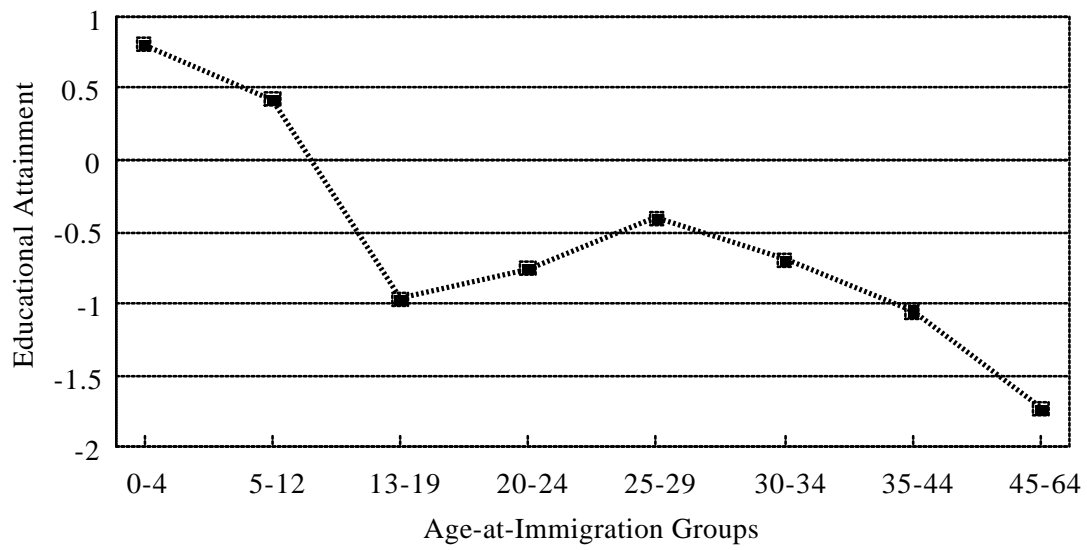

Source: Based on regression results from Table 2, Columns 1 and 3. 


\begin{tabular}{|c|c|c|c|}
\hline $\begin{array}{r}\text { MEANS AND STA } \\
\text { SECOND-GENERATI }\end{array}$ & $\begin{array}{l}\text { TABLE } \\
\text { EVIATIONS OF } \\
\text { NATIVE-PAREN } \\
\end{array}$ & $\begin{array}{l}\text { RIABLES, FIRST- } \\
\text { GE ADULTS, UNI' }\end{array}$ & $\frac{\text { NERATION, }}{\text { STATES, } 1995}$ \\
\hline Variable & First-Generation & Second-Generation & Native-Parentage \\
\hline Educational Attainment & $\begin{array}{l}11.81 \\
(4.24)\end{array}$ & $\begin{array}{l}13.68 \\
(2.67)\end{array}$ & $\begin{array}{l}13.46 \\
(2.44)\end{array}$ \\
\hline Male & $\begin{array}{c}0.49 \\
(0.50)\end{array}$ & $\begin{array}{c}0.50 \\
(0.50)\end{array}$ & $\begin{array}{c}0.49 \\
(0.50)\end{array}$ \\
\hline Age & $\begin{array}{c}40.85 \\
(10.65)\end{array}$ & $\begin{array}{c}44.46 \\
(11.95)\end{array}$ & $\begin{array}{c}41.71 \\
(10.54)\end{array}$ \\
\hline Black & $\begin{array}{c}0.07 \\
(0.26)\end{array}$ & $\begin{array}{c}0.02 \\
(0.14)\end{array}$ & $\begin{array}{c}0.13 \\
(0.34)\end{array}$ \\
\hline Hispanic & $\begin{array}{c}0.47 \\
(0.50)\end{array}$ & $\begin{array}{c}0.20 \\
(0.40)\end{array}$ & $\begin{array}{c}0.03 \\
(0.16)\end{array}$ \\
\hline Married & $\begin{array}{c}0.72 \\
(0.45)\end{array}$ & $\begin{array}{c}0.67 \\
(0.47)\end{array}$ & $\begin{array}{c}0.67 \\
(0.47)\end{array}$ \\
\hline South & $\begin{array}{c}0.24 \\
(0.43)\end{array}$ & $\begin{array}{c}0.23 \\
(0.42)\end{array}$ & $\begin{array}{c}0.38 \\
(0.48)\end{array}$ \\
\hline Non-MSA & $\begin{array}{c}0.05 \\
(0.22)\end{array}$ & $\begin{array}{c}0.11 \\
(0.31)\end{array}$ & $\begin{array}{c}0.22 \\
(0.42)\end{array}$ \\
\hline Age at immigration & $\begin{array}{c}24.79 \\
(11.07)\end{array}$ & n.a. & n.a. \\
\hline Sample size & 7,496 & 4,506 & 56,483 \\
\hline
\end{tabular}

Source: October 1995 Current Population Survey, United States Census Bureau.

Note: Variables are as defined in TableA-1.

n.a. = Variable not applicable.

standard errors for all variables are in parenthesis. 


\begin{tabular}{|c|c|c|c|}
\hline \multicolumn{4}{|c|}{$\begin{array}{ll}\text { TABLE } 2 \\
\end{array}$} \\
\hline \multicolumn{4}{|c|}{$\begin{array}{l}\text { REGRESSION ESTIMATES OF POOLED SAMPLE OF FIRST-GENERATION, SECOND- } \\
\text { GENERATION, AND NATIVE-PARENTAGE ADULTS, UNITED STATES, } 1995\end{array}$} \\
\hline \multicolumn{4}{|c|}{ DEPENDENT VARIABLE: EDUCATIONAL ATTAINMENT } \\
\hline Variable & (1) & $(2)^{\mathrm{a}}$ & $(3)^{\mathbf{b}}$ \\
\hline Constant & $\begin{array}{l}11.408 \\
(71.14)\end{array}$ & $\begin{array}{r}11.500 \\
(73.26)\end{array}$ & $\begin{array}{c}11.49 \\
(71.55)\end{array}$ \\
\hline Male & $\begin{array}{l}0.136 \\
(6.91)\end{array}$ & $\begin{array}{l}0.149 \\
(7.74)\end{array}$ & $\begin{array}{l}0.137 \\
(6.98)\end{array}$ \\
\hline Age & $\begin{array}{c}0.136 \\
(1774)\end{array}$ & $\begin{array}{c}0.129 \\
(1722)\end{array}$ & $\begin{array}{c}0.131 \\
(17.14)\end{array}$ \\
\hline $\mathrm{Age}^{2}$ & $\begin{array}{c}-0.002 \\
(21.28)\end{array}$ & $\begin{array}{c}-0.002 \\
(20.82)\end{array}$ & $\begin{array}{c}-0.002 \\
(20.70)\end{array}$ \\
\hline Black & $\begin{array}{l}-0.689 \\
(20.36)\end{array}$ & $\begin{array}{l}-0.688 \\
(20.56)\end{array}$ & $\begin{array}{l}-0.688 \\
(20.34)\end{array}$ \\
\hline Hispanic & $\begin{array}{c}-2.586 \\
(59.16)\end{array}$ & $\begin{array}{l}-1.317 \\
(23.69)\end{array}$ & $\begin{array}{c}-2.548 \\
(58.21)\end{array}$ \\
\hline Married & $\begin{array}{c}0.306 \\
(14.14)\end{array}$ & $\begin{array}{c}0.322 \\
(15.22)\end{array}$ & $\begin{array}{c}0.306 \\
(14.17)\end{array}$ \\
\hline South & $\begin{array}{c}0.278 \\
(12.63)\end{array}$ & $\begin{array}{l}-0.301 \\
(13.94)\end{array}$ & $\begin{array}{c}-0.280 \\
(2.76)\end{array}$ \\
\hline Non-MSA & $\begin{array}{c}0.810 \\
(34.60)\end{array}$ & $\begin{array}{c}-0.795 \\
(34.67)\end{array}$ & $\begin{array}{l}-0.810 \\
(34.62)\end{array}$ \\
\hline Age at immigration (Ageimmig) & $\begin{array}{c}-0.058 \\
(6.53)\end{array}$ & $\begin{array}{c}-0.068 \\
(7.76)\end{array}$ & n.e. \\
\hline Ageimig $^{2} / 100$ & $\begin{array}{l}0.038 \\
(2.45)\end{array}$ & $\begin{array}{l}0.027 \\
(1.75)\end{array}$ & n.e. \\
\hline First-Generation & $\begin{array}{l}0.539 \\
(4.48)\end{array}$ & n.e. & n.e. \\
\hline Second-Generation & $\begin{array}{c}0.472 \\
(11.63)\end{array}$ & $\begin{array}{l}0.317 \\
(7.95)\end{array}$ & $\begin{array}{l}0.466 \\
(11.49)\end{array}$ \\
\hline \multicolumn{4}{|l|}{ BIRTHPLACE } \\
\hline English speaking countries & n.e. & $\begin{array}{c}1.580 \\
(11.06)\end{array}$ & n.e. \\
\hline Africa & n.e. & $\begin{array}{c}2.970 \\
(10.35)\end{array}$ & n.e. \\
\hline Mexico & n.e. & $\begin{array}{l}-2.442 \\
(17.46)\end{array}$ & n.e. \\
\hline Cuba & n.e. & $\begin{array}{l}1.339 \\
(6.59)\end{array}$ & n.e. \\
\hline S. \& C. America & n.e. & $\begin{array}{l}0.401 \\
(2.62)\end{array}$ & n.e. \\
\hline Caribbean & n.e. & $\begin{array}{l}-0.261 \\
(1.34)\end{array}$ & n.e. \\
\hline Southern Europe & n.e. & $\begin{array}{r}-1.387 \\
(8.33)\end{array}$ & n.e. \\
\hline E. \& C. Europe & n.e. & $\begin{array}{c}1.973 \\
(13.67)\end{array}$ & n.e. \\
\hline
\end{tabular}




\begin{tabular}{|c|c|c|c|}
\hline \multicolumn{4}{|c|}{$\begin{array}{l}\text { TABLE } 2 \text { (continued) } \\
\end{array}$} \\
\hline \multicolumn{4}{|c|}{$\begin{array}{l}\text { REGRESSION ESTIMATES OF POOLED SAMPLE OF FIRST-GENERATION, SECOND- } \\
\text { GENERATION, AND NATIVE-PARENTAGE ADULTS, UNITED STATES, } 1995\end{array}$} \\
\hline \multicolumn{4}{|c|}{ DEPENDENT VARIABLE: EDUCATIONAL ATTAINMENT } \\
\hline Variable & (1) & $(2)^{\mathrm{a}}$ & $(3)^{b}$ \\
\hline N. \& W. Europe & n.e. & $\begin{array}{c}3.262 \\
(10.17)\end{array}$ & n.e. \\
\hline Philippines & n.e. & $\begin{array}{r}1.910 \\
(1129)\end{array}$ & n.e. \\
\hline China & n.e. & 1.130 & n.e. \\
\hline Vietnam & n.e. & $\begin{array}{l}-0.387 \\
(1.79)\end{array}$ & n.e. \\
\hline East Asia & n.e. & $\begin{array}{c}2.112 \\
(11.73)\end{array}$ & n.e. \\
\hline South Asia & n.e. & $\begin{array}{c}3.371 \\
(17.64)\end{array}$ & n.e. \\
\hline Middle East & n.e. & 2.095 & n.e. \\
\hline Other Asia & n.e. & $\begin{array}{r}-0.153 \\
(077)\end{array}$ & n.e. \\
\hline Remaining Countries & n.e. & $\begin{array}{c}1.820 \\
(11.29)\end{array}$ & n.e. \\
\hline \multicolumn{4}{|l|}{ AGE AT IMMIGRATION } \\
\hline 0 to 4 & n.e. & n.e. & $\begin{array}{l}0.818 \\
(5.54)\end{array}$ \\
\hline 5 to 12 & n.e. & n.e. & $\begin{array}{l}0.431 \\
(4.11)\end{array}$ \\
\hline 13 to 19 & n.e. & n.e. & $\begin{array}{l}-0.960 \\
(12.15)\end{array}$ \\
\hline 20 to 24 & n.e. & n.e. & $\begin{array}{c}-0.751 \\
(11.31)\end{array}$ \\
\hline 25 to 29 & n.e. & n.e. & $\begin{array}{l}-0.401 \\
(5.71)\end{array}$ \\
\hline 30 to 34 & n.e. & n.e. & $\begin{array}{c}-0.693 \\
(8.30)\end{array}$ \\
\hline 35 to 44 & n.e. & n.e. & $\begin{array}{l}-1.039 \\
(11.82)\end{array}$ \\
\hline 45 to 64 & n.e. & n.e. & $\begin{array}{l}-1.713 \\
(13.55)\end{array}$ \\
\hline Adjusted $\mathrm{R}^{2}$ & 0.110 & 0.149 & 0.112 \\
\hline Sample size & 68,485 & 68,485 & 68,485 \\
\hline
\end{tabular}

Source: October 1995 Current Population Survey, United States Census Bureau.

Note: Variables are as defined in Table A-1.

n.e. $=$ Variable not entered.

$\mathrm{t}$ statistics are in parenthesis.

${ }^{\mathrm{a}}$ and ${ }^{\mathrm{b}}$ benchmark group is all native-born adults. 


\begin{tabular}{|c|c|c|c|}
\hline \multicolumn{4}{|c|}{$\begin{array}{c}\text { TABLE } 3 \\
\text { SUMMARY STATISTICS OF SELECTED VARIABLES, BY COUNTRY OF ORIGIN, } \\
\text { FIRST-GENERATION ADULTS, UNITED STATES, } 1995\end{array}$} \\
\hline Country of origin & Sample-Size & $\begin{array}{l}\text { Educational } \\
\text { Attainment }\end{array}$ & $\begin{array}{c}\text { Age at } \\
\text { immigration }\end{array}$ \\
\hline English-speaking countries & $\begin{array}{c}720 \\
(9.61)^{\mathrm{a}}\end{array}$ & $\begin{array}{c}13.73 \\
(2.68)^{b}\end{array}$ & $\begin{array}{c}23.70 \\
(11.66)\end{array}$ \\
\hline Africa & $\begin{array}{c}94 \\
(1.25)\end{array}$ & $\begin{array}{l}14.98 \\
(3.26)\end{array}$ & $\begin{array}{l}26.66 \\
(8.54)\end{array}$ \\
\hline Mexico & $\begin{array}{c}1650 \\
(22.01)\end{array}$ & $\begin{array}{c}8.66 \\
(3.83)\end{array}$ & $\begin{array}{l}22.79 \\
(9.94)\end{array}$ \\
\hline Cuba & $\begin{array}{c}233 \\
(3.11)\end{array}$ & $\begin{array}{l}11.96 \\
(3.35)\end{array}$ & $\begin{array}{c}24.04 \\
(13.10)\end{array}$ \\
\hline S. \& C. America & $\begin{array}{c}890 \\
(11.87)\end{array}$ & $\begin{array}{l}11.58 \\
(3.87)\end{array}$ & $\begin{array}{l}25.54 \\
(9.97)\end{array}$ \\
\hline Caribbean & $\begin{array}{c}287 \\
(3.83)\end{array}$ & $\begin{array}{l}11.06 \\
(3.72)\end{array}$ & $\begin{array}{l}26.44 \\
(8.94)\end{array}$ \\
\hline Southern Europe & $\begin{array}{c}360 \\
(4.80)\end{array}$ & $\begin{array}{l}11.64 \\
(4.16)\end{array}$ & $\begin{array}{c}20.26 \\
(11.158)\end{array}$ \\
\hline E. \& C. Europe & $\begin{array}{c}698 \\
(9.31)\end{array}$ & $\begin{array}{l}14.10 \\
(2.96)\end{array}$ & $\begin{array}{c}27.22 \\
(13.82)\end{array}$ \\
\hline N. \& W. Europe & $\begin{array}{c}70 \\
(0.93)\end{array}$ & $\begin{array}{l}15.31 \\
(2.31)\end{array}$ & $\begin{array}{l}22.70 \\
(8.74)\end{array}$ \\
\hline Philippines & $\begin{array}{c}438 \\
(5.84)\end{array}$ & $\begin{array}{l}14.11 \\
(2.82)\end{array}$ & $\begin{array}{c}26.78 \\
(11.28)\end{array}$ \\
\hline China & $\begin{array}{c}259 \\
(3.46)\end{array}$ & $\begin{array}{l}13.60 \\
(4.37)\end{array}$ & $\begin{array}{c}30.61 \\
(11.67)\end{array}$ \\
\hline Vietnam & $\begin{array}{c}191 \\
(2.55)\end{array}$ & $\begin{array}{l}11.99 \\
(4.17)\end{array}$ & $\begin{array}{c}29.18 \\
(13.06)\end{array}$ \\
\hline East Asia & $\begin{array}{c}363 \\
(4.84)\end{array}$ & $\begin{array}{l}14.43 \\
(2.64)\end{array}$ & $\begin{array}{c}27.73 \\
(10.42)\end{array}$ \\
\hline South Asia & $\begin{array}{c}307 \\
(4.10)\end{array}$ & $\begin{array}{l}15.57 \\
(3.04)\end{array}$ & $\begin{array}{l}26.74 \\
(7.86)\end{array}$ \\
\hline Middle East & $\begin{array}{c}183 \\
(2.44)\end{array}$ & $\begin{array}{l}14.33 \\
(3.62)\end{array}$ & $\begin{array}{c}25.58 \\
(10.14)\end{array}$ \\
\hline Other Asia & $\begin{array}{c}252 \\
(3.36)\end{array}$ & $\begin{array}{l}11.71 \\
(4.52)\end{array}$ & $\begin{array}{c}26.10 \\
(10.42)\end{array}$ \\
\hline Remaining Countries & $\begin{array}{c}501 \\
(6.68)\end{array}$ & $\begin{array}{l}13.97 \\
(3.17)\end{array}$ & $\begin{array}{c}25.87 \\
(10.77)\end{array}$ \\
\hline Total & $\begin{array}{c}7,496 \\
(100.00)\end{array}$ & $\begin{array}{l}11.82 \\
(4.23)\end{array}$ & $\begin{array}{c}24.79 \\
(11.07)\end{array}$ \\
\hline
\end{tabular}

Source: October 1995 Current Population Survey, United States Census Bureau.

Note: Variables are as defined in Table A- 1 .

${ }^{\text {a }}$ denotes percent foreign-born in column 2 .

${ }^{\mathrm{b}}$ standard errors of all variables are indicated in parenthesis. 


\begin{tabular}{|c|c|c|}
\hline \multicolumn{3}{|c|}{$\begin{array}{l}\text { SUMMARY STATISTICS OF EDUCATIONAL ATTAINMENT, BY AGE AT } \\
\text { IMMIGRATION, FIRST-GENERATION ADULTS, UNITED STATES, } 1995\end{array}$} \\
\hline Age at immigration & Sample Size & Educational Attainment \\
\hline 0 to 4 & $\begin{array}{c}305 \\
(4.07)^{\mathrm{a}}\end{array}$ & $\begin{array}{c}13.71 \\
(2.69)^{b}\end{array}$ \\
\hline 5 to 12 & $\begin{array}{c}620 \\
(8.27)\end{array}$ & $\begin{array}{l}13.04 \\
(3.08)\end{array}$ \\
\hline 13 to 19 & $\begin{array}{c}1172 \\
(15.64)\end{array}$ & $\begin{array}{l}11.19 \\
(3.96)\end{array}$ \\
\hline 20 to 24 & $\begin{array}{c}1656 \\
(22.09)\end{array}$ & $\begin{array}{l}11.55 \\
(4.15)\end{array}$ \\
\hline 25 to 29 & $\begin{array}{c}1436 \\
(19.16)\end{array}$ & $\begin{array}{l}12.15 \\
(4.43)\end{array}$ \\
\hline 30 to 34 & $\begin{array}{c}994 \\
(13.26)\end{array}$ & $\begin{array}{l}11.91 \\
(4.44)\end{array}$ \\
\hline 35 to 44 & $\begin{array}{c}889 \\
(11.86)\end{array}$ & $\begin{array}{l}11.52 \\
(4.62)\end{array}$ \\
\hline 45 to 64 & $\begin{array}{c}424 \\
(5.65)\end{array}$ & $\begin{array}{l}10.69 \\
(4.95)\end{array}$ \\
\hline Total & $\begin{array}{c}7,496 \\
(100.00)\end{array}$ & $\begin{array}{l}11.82 \\
(4.23)\end{array}$ \\
\hline
\end{tabular}

Source: October 1995 Current Population Survey, United States Census Bureau.

Note: Variables are as defined in Table A-1.

${ }^{a}$ denotes percent in age at immigration group.

${ }^{\mathrm{b}}$ standard errors are indicated in parenthesis. 


\begin{tabular}{|c|c|c|c|}
\hline \multicolumn{3}{|c|}{$\begin{array}{ll}\text { TABLE } 5 \\
\end{array}$} & $\begin{array}{l}\text { REGRESSION ESTIMATES OF FIRST-GENERATION ADULTS, } \\
\text { UNITED STATES, } 1995\end{array}$ \\
\hline \multicolumn{4}{|c|}{ DEPENDENT VARIABLE: EDUCATIONAL ATTAINMENT } \\
\hline Variable & (1) & $(2)^{\mathrm{a}}$ & $(3)^{\mathbf{b}}$ \\
\hline Constant & $\begin{array}{c}12.97 \\
(18.88)\end{array}$ & $\begin{array}{l}14.37 \\
(21.92)\end{array}$ & $\begin{array}{c}12.78 \\
(17.65)\end{array}$ \\
\hline Male & $\begin{array}{l}0.462 \\
(5.43)\end{array}$ & $\begin{array}{l}0.520 \\
(6.54)\end{array}$ & $\begin{array}{l}0.469 \\
(5.53)\end{array}$ \\
\hline Age & $\begin{array}{l}0.111 \\
(3.29)\end{array}$ & $\begin{array}{l}0.062 \\
(1.98)\end{array}$ & $\begin{array}{l}0.075 \\
(2.18)\end{array}$ \\
\hline $\mathrm{Age}^{2}$ & $\begin{array}{r}-0.002 \\
(4.29)\end{array}$ & $\begin{array}{l}-0.001 \\
(3.19)\end{array}$ & $\begin{array}{r}-0.001 \\
(3.22)\end{array}$ \\
\hline Black & $\begin{array}{c}-0.328 \\
(1.97)\end{array}$ & $\begin{array}{r}-0.284 \\
(1.59)\end{array}$ & $\begin{array}{r}-0.317 \\
(1.90)\end{array}$ \\
\hline Hispanic & $\begin{array}{l}-3.879 \\
(42.99)\end{array}$ & $\begin{array}{c}-1.086 \\
(5.56)\end{array}$ & $\begin{array}{l}-3.817 \\
(42.21)\end{array}$ \\
\hline Married & $\begin{array}{l}0.043 \\
(0.44)\end{array}$ & $\begin{array}{l}0.162 \\
(1.79)\end{array}$ & $\begin{array}{l}0.048 \\
(0.49)\end{array}$ \\
\hline South & $\begin{array}{l}0.312 \\
(2.87)\end{array}$ & $\begin{array}{l}0.033 \\
(0.32)\end{array}$ & $\begin{array}{l}0.287 \\
(2.64)\end{array}$ \\
\hline Non-MSA & $\begin{array}{r}-0.700 \\
(4.00)\end{array}$ & $\begin{array}{l}-0.465 \\
(2.83)\end{array}$ & $\begin{array}{c}-0.702 \\
(4.02)\end{array}$ \\
\hline Age at immigration (Ageimmig) & $\begin{array}{c}-0.053 \\
(4.11)\end{array}$ & $\begin{array}{c}-0.068 \\
(5.56)\end{array}$ & n.e. \\
\hline Ageimmig $^{2} / 100$ & $\begin{array}{l}0.028 \\
(1.19)\end{array}$ & $\begin{array}{l}0.038 \\
(1.74)\end{array}$ & n.e. \\
\hline \multicolumn{4}{|l|}{ BIRTHPLACE } \\
\hline Africa & n.e. & $\begin{array}{l}1.223 \\
(3.24)\end{array}$ & n.e. \\
\hline Mexico & n.e. & $\begin{array}{l}-4.217 \\
(17.41)\end{array}$ & n.e. \\
\hline Cuba & n.e. & $\begin{array}{c}-0.498 \\
(1.55)\end{array}$ & n.e. \\
\hline S. \& C. America & n.e. & $\begin{array}{c}-1.320 \\
(5.70)\end{array}$ & n.e. \\
\hline Caribbean & n.e. & $\begin{array}{c}-1.988 \\
(7.65)\end{array}$ & n.e. \\
\hline Southern Europe & n.e. & $\begin{array}{c}-2.731 \\
(11.88)\end{array}$ & n.e. \\
\hline E. \& C. Europe & n.e. & $\begin{array}{l}0.589 \\
(3.07)\end{array}$ & n.e. \\
\hline N. \& W. Europe & n.e. & $\begin{array}{l}1.739 \\
(4.04)\end{array}$ & n.e. \\
\hline
\end{tabular}




\begin{tabular}{|c|c|c|c|}
\hline & contin & & \\
\hline REGRESSI & $\frac{\text { IRST }}{\text { ATES, }}$ & ION & \\
\hline DEPEND & UCAT & TAIN & \\
\hline Variable & (1) & $(2)^{a}$ & $(3)^{b}$ \\
\hline Philippines & n.e. & $\begin{array}{l}0.497 \\
(2.30)\end{array}$ & n.e. \\
\hline China & n.e. & $\begin{array}{c}-0.334 \\
(1.29)\end{array}$ & n.e. \\
\hline Vietnam & n.e. & $\begin{array}{c}-1.924 \\
(6.70)\end{array}$ & n.e. \\
\hline East Asia & n.e. & $\begin{array}{l}0.654 \\
(2.84)\end{array}$ & n.e. \\
\hline South Asia & n.e. & $\begin{array}{l}1.872 \\
(7.68)\end{array}$ & n.e. \\
\hline Middle East & n.e. & $\begin{array}{l}0.586 \\
(2.02)\end{array}$ & n.e. \\
\hline Other Asia & n.e. & $\begin{array}{r}-1.667 \\
(6444)\end{array}$ & n.e. \\
\hline Remaining Countries & n.e. & $\begin{array}{l}0.281 \\
(1.39)\end{array}$ & n.e. \\
\hline AGE AT IMMIGRATION & & & \\
\hline 0 to 4 & n.e. & n.e. & $\begin{array}{l}1.119 \\
(4.83)\end{array}$ \\
\hline 5 to 12 & n.e. & n.e. & $\begin{array}{l}0.826 \\
(4.67)\end{array}$ \\
\hline 13 to 19 & n.e. & n.e. & $\begin{array}{l}-0.404 \\
(2.77)\end{array}$ \\
\hline 20 to 24 & n.e. & n.e. & $\begin{array}{c}-0.306 \\
(2.30)\end{array}$ \\
\hline 30 to 34 & n.e. & n.e. & $\begin{array}{c}-0.229 \\
(1.50)\end{array}$ \\
\hline 35 to 44 & n.e. & n.e. & $\begin{array}{c}-0.605 \\
(3.72)\end{array}$ \\
\hline 45 to 64 & n.e. & n.e. & $\begin{array}{l}-1.287 \\
(5.82)\end{array}$ \\
\hline Adjusted $\mathrm{R}^{2}$ & 0.215 & 0.322 & 0.218 \\
\hline Sample size & 7,496 & 7,496 & 7,496 \\
\hline
\end{tabular}

Source: October 1995 Current Population Survey, United States Census Bureau.

Note: Variables are as defined in Table A- 1 .

n.e. $=$ Variable not entered. $\mathrm{t}$ statistics are in parenthesis.

${ }^{a}$ benchmark group is all foreign-born adults from English-speaking countries.

${ }^{\mathrm{b}}$ benchmark group is all foreign-born adults who immigrated between age 25 to 29. 


\begin{tabular}{|c|c|c|c|c|}
\hline \\
\hline \multicolumn{5}{|c|}{$\begin{array}{l}\text { REGRESSION ESTIMATES OF FIRST-GENERATION ADULTS BY HISPANIC/NON- } \\
\text { HISPANIC ORIGIN, UNITED STATES, } 1995\end{array}$} \\
\hline \multicolumn{5}{|c|}{ DEPENDENT VARIABLE: EDUCATIONAL ATTAINMENT } \\
\hline \multirow[b]{2}{*}{ Variable } & \multicolumn{2}{|c|}{ Hispanic } & \multicolumn{2}{|c|}{ Non-Hispanic } \\
\hline & (1) & (2) & (1) & (2) \\
\hline Constant & $\begin{array}{l}11.807 \\
(10.03)\end{array}$ & $\begin{array}{l}9 / 678 \\
(7.84)\end{array}$ & $\begin{array}{l}11.821 \\
(14.21)\end{array}$ & $\begin{array}{l}12.176 \\
(13.85)\end{array}$ \\
\hline Male & $\begin{array}{l}0.020 \\
(0.13)\end{array}$ & $\begin{array}{l}0.056 \\
(0.38)\end{array}$ & $\begin{array}{l}0.756 \\
(7.46)\end{array}$ & $\begin{array}{l}0.755 \\
(7.45)\end{array}$ \\
\hline Age & $\begin{array}{l}0.066 \\
(1.12)\end{array}$ & $\begin{array}{l}0.016 \\
(0.27)\end{array}$ & $\begin{array}{l}0.122 \\
(3.03)\end{array}$ & $\begin{array}{l}0.113 \\
(2.69)\end{array}$ \\
\hline $\mathrm{Age}^{2}$ & $\begin{array}{r}-0.079 \\
(1.13)\end{array}$ & $\begin{array}{l}-0.030 \\
(0.42)\end{array}$ & $\begin{array}{l}-0.002 \\
(4.24)\end{array}$ & $\begin{array}{l}-0.002 \\
(3.84)\end{array}$ \\
\hline Black & $\begin{array}{l}2.516 \\
(5.50)\end{array}$ & $\begin{array}{l}2.432 \\
(5.33)\end{array}$ & $\begin{array}{r}-0.821 \\
(4.80)\end{array}$ & $\begin{array}{l}-0.796 \\
(4.66)\end{array}$ \\
\hline Married & $\begin{array}{l}-0.274 \\
(1.70)\end{array}$ & $\begin{array}{l}-0.256 \\
(1.59)\end{array}$ & $\begin{array}{l}0.261 \\
(2.20)\end{array}$ & $\begin{array}{l}0.246 \\
(2.07)\end{array}$ \\
\hline South & $\begin{array}{l}0.280 \\
(1.63)\end{array}$ & $\begin{array}{l}0.224 \\
(1.31)\end{array}$ & $\begin{array}{l}0.331 \\
(2.38)\end{array}$ & $\begin{array}{l}0.317 \\
(2.27)\end{array}$ \\
\hline Non-MSA & $\begin{array}{l}-1.197 \\
(4.20)\end{array}$ & $\begin{array}{l}-1.221 \\
(4.30)\end{array}$ & $\begin{array}{l}-0.257 \\
(1.18)\end{array}$ & $\begin{array}{r}-0.235 \\
(1.08)\end{array}$ \\
\hline Age at immigration (Ageimmig) & $\begin{array}{l}-0.184 \\
(7.27)\end{array}$ & n.e. & $\begin{array}{l}0.009 \\
(0.59)\end{array}$ & n.e. \\
\hline Ageimmig ${ }^{2} / 100$ & $\begin{array}{l}0.002 \\
(4.06)\end{array}$ & n.e. & $\begin{array}{l}-0.056 \\
(2.15)\end{array}$ & n.e. \\
\hline \multicolumn{5}{|l|}{ AGE AT IMMIGRATION } \\
\hline 0 to 4 & n.e. & $\begin{array}{l}3.092 \\
(6.96)\end{array}$ & n.e. & $\begin{array}{l}0.148 \\
(0.56)\end{array}$ \\
\hline 5 to 12 & n.e. & $\begin{array}{l}2.402 \\
(7.84)\end{array}$ & n.e. & $\begin{array}{l}-0.103 \\
(0.49)\end{array}$ \\
\hline 13 to 19 & n.e. & $\begin{array}{l}0.133 \\
(0.56)\end{array}$ & n.e. & $\begin{array}{l}-0.641 \\
(3.46)\end{array}$ \\
\hline 20 to 24 & n.e. & $\begin{array}{c}-0.013 \\
(0.06)\end{array}$ & n.e. & $\begin{array}{c}-0.368 \\
(2.31)\end{array}$ \\
\hline 30 to 34 & n.e. & $\begin{array}{l}-0.243 \\
(0.89)\end{array}$ & n.e. & $\begin{array}{l}0.352 \\
(1.97)\end{array}$ \\
\hline 35 to 44 & n.e. & $\begin{array}{r}-0.469 \\
(1.49)\end{array}$ & n.e. & $\begin{array}{l}0.782 \\
(4.24)\end{array}$ \\
\hline 45 to 64 & n.e. & $\begin{array}{r}-1.509 \\
(3.34)\end{array}$ & n.e. & $\begin{array}{c}-1.338 \\
(5.46)\end{array}$ \\
\hline Adjusted $\mathrm{R}^{2}$ & 0.061 & 0.068 & 0.057 & 0.061 \\
\hline Sample size & 2,858 & 2,858 & 4,638 & 4,638 \\
\hline
\end{tabular}

Source: October 1995 Current Population Survey, United States Census Bureau.

Note: Variables are as defined in Table A-1.

n.e. $=$ Variable not entered.

$\mathrm{t}$ statistics are in parenthesis. 


\begin{tabular}{|c|c|c|c|c|}
\hline $\begin{array}{r}\text { REGRESSION ES } \\
\text { NA }\end{array}$ & $\begin{array}{l}\text { MATES OF FIR } \\
\text { VE-PARENTAG }\end{array}$ & $\begin{array}{l}\text { ABLE } 7 \\
\text { IENERATIC } \\
\text { DULTS, UN }\end{array}$ & OND-GEI & $\underline{\mathrm{ATION}}, \mathrm{AND}$ \\
\hline DEF & NDENT VARIAE & EDUCATIC & ATTAINM & \\
\hline Variable & First-Generation & $\begin{array}{c}\text { Second- } \\
\text { Generation }\end{array}$ & $\begin{array}{c}\text { Native- } \\
\text { Parentage }\end{array}$ & All Native-Born \\
\hline Constant & $\begin{array}{l}12.97 \\
(18.88)\end{array}$ & $\begin{array}{l}11.775 \\
(19.93)\end{array}$ & $\begin{array}{l}11.35 \\
(69.54)\end{array}$ & $\begin{array}{c}11.32 \\
(72.03)\end{array}$ \\
\hline Male & $\begin{array}{l}0.462 \\
(5.43)\end{array}$ & $\begin{array}{l}0.250 \\
(3.32)\end{array}$ & $\begin{array}{l}0.091 \\
(4.56)\end{array}$ & $\begin{array}{l}0.103 \\
(5.34)\end{array}$ \\
\hline Age & $\begin{array}{l}0.111 \\
(3.29)\end{array}$ & $\begin{array}{l}0.136 \\
(4.94)\end{array}$ & $\begin{array}{c}0.136 \\
(17.43)\end{array}$ & $\begin{array}{c}0.137 \\
(18.34)\end{array}$ \\
\hline $\mathrm{Age}^{2}$ & $\begin{array}{l}-0.002 \\
(4.29)\end{array}$ & $\begin{array}{l}-0.002 \\
(6.45)\end{array}$ & $\begin{array}{c}-0.002 \\
(20.55)\end{array}$ & $\begin{array}{l}-0.002 \\
(21.79)\end{array}$ \\
\hline Black & $\begin{array}{l}-0.328 \\
(1.97)\end{array}$ & $\begin{array}{l}-0.365 \\
(1.29)\end{array}$ & $\begin{array}{l}-0.709 \\
(21.55)\end{array}$ & $\begin{array}{l}-0.707 \\
(21.58)\end{array}$ \\
\hline Hispanic & $\begin{array}{l}-3.879 \\
(42.99)\end{array}$ & $\begin{array}{l}-1.650 \\
(14.66)\end{array}$ & $\begin{array}{l}-1.254 \\
(18.35)\end{array}$ & $\begin{array}{l}-1.333 \\
(23.28)\end{array}$ \\
\hline Married & $\begin{array}{l}0.043 \\
(0.44)\end{array}$ & $\begin{array}{l}0.432 \\
(5.26)\end{array}$ & $\begin{array}{c}0.333 \\
(15.25)\end{array}$ & $\begin{array}{c}0.339 \\
(16.06)\end{array}$ \\
\hline South & $\begin{array}{l}0.312 \\
(2.87)\end{array}$ & $\begin{array}{r}-0.012 \\
(0.12)\end{array}$ & $\begin{array}{c}-0.343 \\
(15.82)\end{array}$ & $\begin{array}{l}-0.328 \\
(15.43)\end{array}$ \\
\hline MSA & $\begin{array}{l}-0.700 \\
(4.00)\end{array}$ & $\begin{array}{l}0.880 \\
(8.30)\end{array}$ & $\begin{array}{c}0.804 \\
(35.70)\end{array}$ & $\begin{array}{c}0.809 \\
(36.65)\end{array}$ \\
\hline Age at immigration & $\begin{array}{r}-0.053 \\
(4.11)\end{array}$ & n.e. & n.e. & n.e. \\
\hline Ageimig $^{2} / 100$ & $\begin{array}{l}0.028 \\
(1.19)\end{array}$ & n.e. & n.e. & n.e. \\
\hline Mother foreign-born & n.e. & n.e. & n.e. & $\begin{array}{l}0.400 \\
(5.91)\end{array}$ \\
\hline Father foreign-born & n.e. & n.e. & n.e. & $\begin{array}{l}0.342 \\
(5.64)\end{array}$ \\
\hline $\begin{array}{l}\text { Both parents foreign- } \\
\text { born }\end{array}$ & n.e. & n.e. & n.e. & $\begin{array}{l}0.212 \\
(3.47)\end{array}$ \\
\hline Adjusted $\mathrm{R}^{2}$ & 0.215 & 0.095 & 0.062 & 0.065 \\
\hline Sample size & 7,496 & 4,506 & 56,483 & 60,989 \\
\hline
\end{tabular}

Source: Current Population Survey, United States Census Bureau.

Note: Variables are as defined in Table A-1.

n.e. $=$ Variable not entered.

$\mathrm{t}$ statistics are in parenthesis. 


\section{APPENDEX}

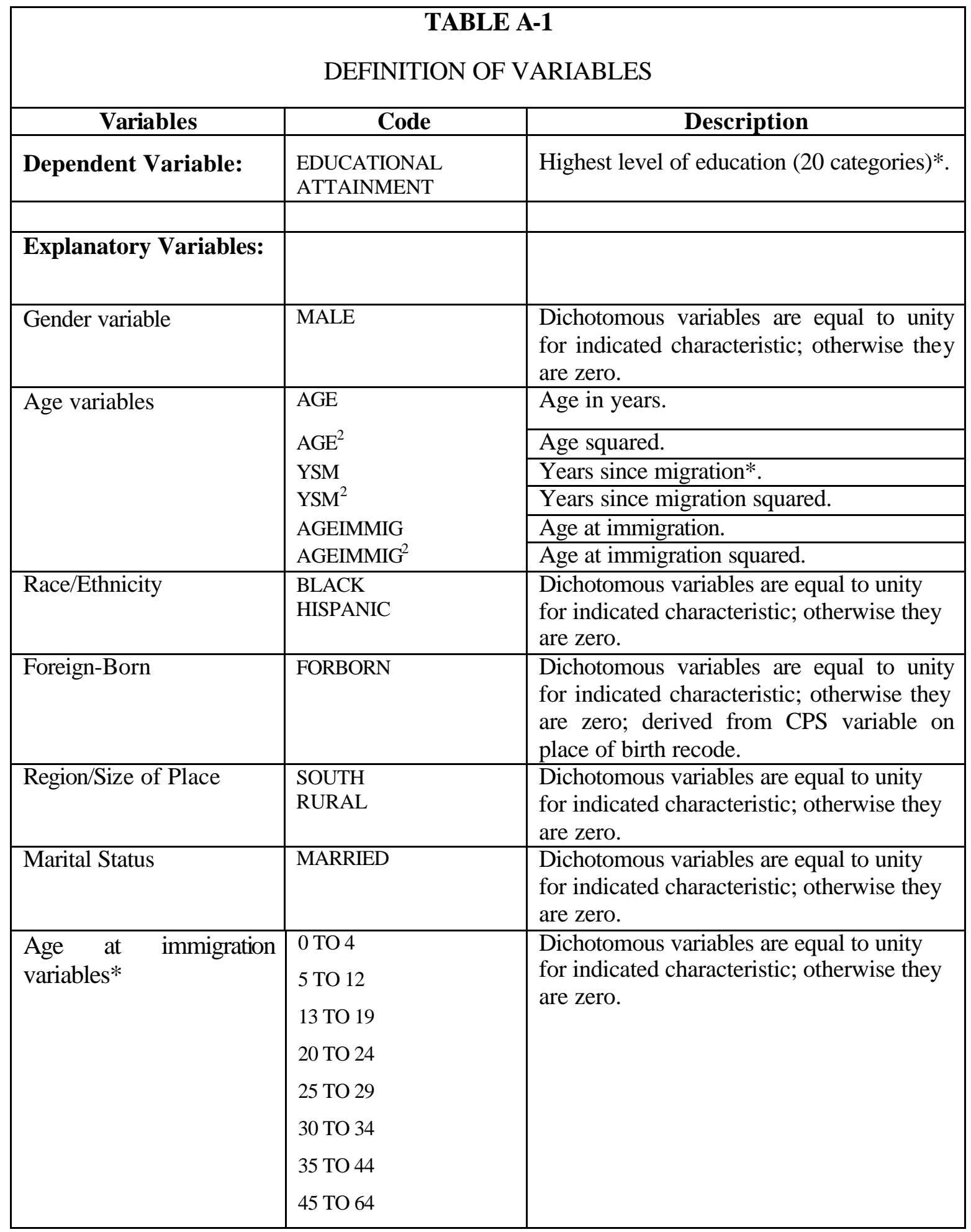




\begin{tabular}{|c|c|c|}
\hline \multicolumn{3}{|c|}{$\begin{array}{c}\text { TABLE A-1 } \\
\text { DEFINITION OF VARIABLES }\end{array}$} \\
\hline Variables & Code & Description \\
\hline $\begin{array}{l}\text { Country-of -origin } \\
\text { variables* }\end{array}$ & $\begin{array}{l}\text { AFRICA } \\
\text { MEXICO } \\
\text { CUBA } \\
\text { S. \& C. AMERICA* } \\
\text { CARIBBEAN* } \\
\text { SOUTHERN EUROPE* } \\
\text { E. \& C. EUROPE* } \\
\text { N. \& W. EUROPE* } \\
\text { PHILIPPINES } \\
\text { CHINA } \\
\text { VIETNAM } \\
\text { EASTASIA* } \\
\text { SOUTHASIA* } \\
\text { MIDDLE EAST* } \\
\text { OTHER ASIA* } \\
\text { ENGLISH SPEAKING } \\
\text { COUNTIES* } \\
\text { REMAINING } \\
\text { COUNTRIES* }\end{array}$ & $\begin{array}{l}\text { Dichotomous variables are equal to unity } \\
\text { for indicated characteristic; otherwise they } \\
\text { are zero. }\end{array}$ \\
\hline $\begin{array}{l}\text { Immigrant Generation } \\
\text { variables }\end{array}$ & $\begin{array}{l}\text { FIRST-GENERATION } \\
\text { SECOND- } \\
\text { GENERATION } \\
\text { MOTHER FOREIGN- } \\
\text { BORN } \\
\text { FATHER FOREIGN- } \\
\text { BORN } \\
\text { BOTH PARENTS } \\
\text { FOREIGN-BORN }\end{array}$ & $\begin{array}{l}\text { Dichotomous variables are equal to unity } \\
\text { for indicated characteristic; otherwise they } \\
\text { are zero. }\end{array}$ \\
\hline
\end{tabular}


Educational Attainment: The following categories were used for defining the number of years of schooling completed by the respondent: "no school completed or completed less than or equal to $4^{\text {th }}$ grade" $=2.5$ years; "completed between $5^{\text {th }}$ and $8^{\text {th }}$ grade" $=7$ years; "completed $9^{\text {th }}$ grade" $=9$ years; "completed $10^{\text {th }}$ grade" $=10$ years; "completed $11^{\text {th }}$ grade" $=11$ years; "completed $12^{\text {th }}$ grade with or without diploma, or completed GED" = 12 years; "some college, no degree, or associate degree" = 14 years; "Bachelors degree" = 16 years; "Masters degree" = 17.5 years; "Professional degree" = 18 years; "Doctorate degree" $=20$ years.

YSM: The CPS provides categorical information on year of mmigration to the U.S. The CPS calculations used 1995 as the base year. The year of entry information is converted into a continuous measure (YSM) using the following values: "1992-1995" = 1.75 years; "1990-1991" = 4.25 years; "1988-1989" = 6.25 years; "1986-1987" = 8.25 years; "1984$1985 "=10.25$ years; "1982-1983" = 12.25 years; "1980-1981" = 14.25 years; "1975$1979 "=17.75 ; " 1970-1974 "=22.75: " 1965-1969 "=27.75 ; " 1960-1964 "=32.75$; $" 1950-1959 "=40.25$; "Before 1950" = 54.75.

Age at immigration: Ageimmig is calculated by subtracting YSM from current age. Thus ageimmig $=$ YSM - Age. YSM is calculated as explained above. This approximation, however, results in some negative values for 'ageimmig' but only for the two earliest periods (1950-59 and pre-1950). For example, a 34 year old, who migrated in 1957 (at the age of 1), has his YSM approximated as 35.5 and hence gets a -1.25 value for ageimmig. It is reasonable to assume that all the adults who get a negative calculated ageimmig probably immigrated at a very young age, therefore they are assigned a value of zero. Categorical age at immigration (dichotomous) variables were computed from the continuous variable.

Country of origin Variables: The country dummy variables are self-explanatory except for those discussed below. 
SOUTHERN EUROPE includes Albania, Italy, Malta, Monaco, Portugal, Madeira Island, Spain, Vatican City, Yugoslavia.

EAST and CENTRAL EUROPE includes Austria, Belgium, Czechoslovakia, Denmark, Germany (East and West), Berlin (East and West), Liechtenstein, Luxembourg, Netherlands, Switzerland, Hungary, Poland, Romania, former USSR, Baltic States, Estonia, Latvia, Lithuania.

NORTH and WEST EUROPE includes Faroe Islands, Jan Mayen, Finland, Iceland, Norway, Sweden, Svalbard, Lapland, Andorra, France, Guernsey, Jersey, Azores Islands, Madeira Islands.

SOUTH ASIA includes Afghanistan, Bangladesh, Bhutan, Burma, India, Pakistan, Sri Lanka, Nepal.

EAST ASIA includes Japan, Korea, Macau, Mongolia, Taiwan.

OTHER ASIA (Primarily South-east Asia) includes Brunei, Cambodia, Hong Kong, Indonesia, Laos, Malaysia, Singapore, Thailand, Indochina.

MIDDLE EAST includes Bahrain, Cyprus, Iran, Iraq, Israel, Jordan, Kuwait, Lebanon, Quatar, Saudi Arabia, Syria, Turkey, United Arab Emirates, Yemen, Mesopotamia, Palestine, Persian Gulf States, West Bank.

ENGLISH-SPEAKING COUNTRIES includes United Kingdom, England, Ireland, Scotland, Wales, Canada, Australia, New Zealand; English-speaking parts of Caribbean islands (Bahamas, British Virgin Islands, Jamaica, British West Indies).

REMAINING COUNTRIES includes all countries not included in the country dummies - the major composition being Oceania (except Australia and New Zealand). 


\section{IZA Discussion Papers}

\begin{tabular}{|c|c|c|c|c|}
\hline No. & Author(s) & Title & Area & Date \\
\hline 716 & $\begin{array}{l}\text { M. Rosholm } \\
\text { L. Skipper }\end{array}$ & $\begin{array}{l}\text { Is Labour Market Training a Curse for the } \\
\text { Unemployed? Evidence from a Social } \\
\text { Experiment }\end{array}$ & 6 & $02 / 03$ \\
\hline 717 & $\begin{array}{l}\text { A. Hijzen } \\
\text { H. Görg } \\
\text { R. C. Hine }\end{array}$ & $\begin{array}{l}\text { International Fragmentation and Relative Wages } \\
\text { in the UK }\end{array}$ & 2 & $02 / 03$ \\
\hline 718 & E. Schlicht & Consistency in Organization & 1 & $02 / 03$ \\
\hline 719 & $\begin{array}{l}\text { J. Albrecht } \\
\text { P. Gautier } \\
\text { S. Vroman }\end{array}$ & $\begin{array}{l}\text { Equilibrium Directed Search with Multiple } \\
\text { Applications }\end{array}$ & 3 & $02 / 03$ \\
\hline 720 & T. Palokangas & $\begin{array}{l}\text { Labour Market Regulation, Productivity- } \\
\text { Improving R\&D and Endogenous Growth }\end{array}$ & 3 & $02 / 03$ \\
\hline 721 & $\begin{array}{l}\text { H. Battu } \\
\text { M. Mwale } \\
\text { Y. Zenou }\end{array}$ & $\begin{array}{l}\text { Do Oppositional Identities Reduce Employment } \\
\text { for Ethnic Minorities? }\end{array}$ & 1 & $02 / 03$ \\
\hline 722 & $\begin{array}{l}\text { C. K. Spiess } \\
\text { F. Büchel } \\
\text { G. G. Wagner }\end{array}$ & $\begin{array}{l}\text { Children's School Placement in Germany: Does } \\
\text { Kindergarten Attendance Matter? }\end{array}$ & 6 & $02 / 03$ \\
\hline 723 & $\begin{array}{l}\text { M. Coles } \\
\text { B. Petrongolo }\end{array}$ & $\begin{array}{l}\text { A Test between Unemployment Theories Using } \\
\text { Matching Data }\end{array}$ & 3 & $02 / 03$ \\
\hline 724 & $\begin{array}{l}\text { J. T. Addison } \\
\text { R. Bailey } \\
\text { W. S. Siebert }\end{array}$ & $\begin{array}{l}\text { The Impact of Deunionisation on Earnings } \\
\text { Dispersion Revisited }\end{array}$ & 2 & $02 / 03$ \\
\hline 725 & S. Habermalz & An Examination of Sheepskin Effects Over Time & 1 & $02 / 03$ \\
\hline 726 & S. Habermalz & $\begin{array}{l}\text { Job Matching and the Returns to Educational } \\
\text { Signals }\end{array}$ & 1 & $02 / 03$ \\
\hline 727 & $\begin{array}{l}\text { M. Raiser } \\
\text { M. Schaffer } \\
\text { J. Schuchardt }\end{array}$ & Benchmarking Structural Change in Transition & 4 & $02 / 03$ \\
\hline 728 & $\begin{array}{l}\text { M. Lechner } \\
\text { J. A. Smith }\end{array}$ & What is the Value Added by Caseworkers? & 6 & $02 / 03$ \\
\hline 729 & $\begin{array}{l}\text { A. Voicu } \\
\text { H. Buddelmeyer }\end{array}$ & $\begin{array}{l}\text { Children and Women's Participation Dynamics: } \\
\text { Transitory and Long-Term Effects }\end{array}$ & 3 & $02 / 03$ \\
\hline 730 & $\begin{array}{l}\text { M. Piva } \\
\text { M. Vivarelli }\end{array}$ & $\begin{array}{l}\text { Innovation and Employment: Evidence from } \\
\text { Italian Microdata }\end{array}$ & 2 & $02 / 03$ \\
\hline 731 & $\begin{array}{l}\text { B. R. Chiswick } \\
\text { N. DebBurman }\end{array}$ & $\begin{array}{l}\text { Educational Attainment: Analysis by Immigrant } \\
\text { Generation }\end{array}$ & 1 & $2 / 03$ \\
\hline
\end{tabular}

An updated list of IZA Discussion Papers is available on the center's homepage www.iza.org. 